OPEN ACCESS

Edited by:

Mohamed Boutjdir,

Veterans Affairs New York Harbor

Healthcare System, United States

Reviewed by:

Caroline Jefferies,

Cedars-Sinai Medical Center,

United States

Katherine R. Martin,

Walter and Eliza Hall Institute of

Medical Research, Australia

*Correspondence:

Chengwu Shen

525500290@qq.com

Specialty section:

This article was submitted to

Inflammation,

a section of the journal

Frontiers in Immunology

Received: 27 August 2018 Accepted: 19 November 2018 Published: 12 December 2018

Citation:

Zhang $R, X u L$, Zhang D, Hu B, Luo Q

Han D, Li J and Shen C (2018)

Cardioprotection of Ginkgolide B on

Myocardial

Ischemia/Reperfusion-Induced Inflammatory Injury via Regulation of

A20-NF-кB Pathway.

Front. Immunol. 9:2844.

doi: 10.3389/fimmu.2018.02844

\section{Cardioprotection of Ginkgolide B on Myocardial Ischemia/Reperfusion-Induced Inflammatory Injury via Regulation of A20-NF-кB Pathway}

\author{
Rui Zhang ${ }^{1}$, Lin $\mathrm{Xu}^{2}$, Dong Zhang ${ }^{3}$, Bo Hu${ }^{4}$, Qi Luo ${ }^{1}$, Dan Han ${ }^{5}$, Jiangbing $\mathrm{Li}^{6}$ and \\ Chengwu Shen ${ }^{*}$
}

${ }^{1}$ Department of Pharmacy, Shandong Provincial Hospital Affiliated to Shandong University, Jinan, China, ${ }^{2}$ Department of Thoracic Surgery, Shandong Provincial Hospital Affiliated to Shandong University, Jinan, China, ${ }^{3}$ Department of Urology, Shandong Provincial Hospital Affiliated to Shandong University, Jinan, China, ${ }^{4}$ Minimally Invasive Urology Center, Shandong Provincial Hospital Affiliated to Shandong University, Jinan, China, ${ }^{5}$ Department of Pharmacy, Nanjing Drum Tower Hospital, The Affiliated Hospital of Nanjing University Medical School, Nanjing, China, ${ }^{6}$ Department of Cardiology, Shandong Provincial Hospital Affiliated to Shandong University, Jinan, China

Inflammation urges most of the characteristics of plaques involved in the pathogenesis of myocardial ischemia/reperfusion injury (MI/RI). In addition, inflammatory signaling pathways not only mediate the properties of plaques that precipitate ischemia/reperfusion (I/R) but also influence the clinical consequences of the post-infarction remodeling and heart failure. Here, we studied whether Ginkgolide B (GB), an effective anti-inflammatory monomer, improved Ml/RI via suppression of inflammation. Left anterior descending (LAD) coronary artery induced ischemia/reperfusion (I/R) of rats or A20 silencing mice, as well as hypoxia/reoxygenation $(\mathrm{H} / \mathrm{R})$ induced damages of primary cultured rat neonatal ventricular myocytes or A20 silencing ventricular myocytes, respectively, served as $\mathrm{MI} / \mathrm{RI}$ model in vivo and in vitro to discuss the anti-I/R injury properties of GB. We found that GB significantly alleviated the symptoms of $\mathrm{Ml} / \mathrm{Rl}$ evidently by reducing infarct size, preventing ultrastructural changes of myocardium, depressing Polymorphonuclears (PMNs) infiltration, lessening histopathological damage and suppressing the excessive inflammation. Further study demonstrated that GB remarkably inhibited NF-кB p65 subunit translocation, ІкB- $\alpha$ phosphorylation, IKK- $\beta$ activity, as well as the downstream inflammatory cytokines and proteins expressions via zinc finger protein A20. In conclusion, GB could alleviate MI/RI-induced inflammatory response through A20-NF-кB signal pathway, which may give us new insights into the preventive strategies for $\mathrm{Ml} / \mathrm{Rl}$ disease.

Keywords: Ginkgolide B, Myocardial ischemia/reperfusion injury, Inflammation, A20, NF-кB 


\section{INTRODUCTION}

Myocardial ischemia/reperfusion injury (MI/RI) with high morbidity and mortality rates has become one of the decisive factors for the events of cardiovascular diseases $(1,2)$. The mechanisms of MI/RI refer to a series of complicated pathological processes, including inflammatory response, calcium overload, complement activation, cell autophagy, and apoptosis (3). And, it has repeatedly been shown that the earliest phases of ischemia/reperfusion (I/R) are dominated by an acute inflammatory response. Presently, the mechanisms driving this acute and robust inflammatory response are still unknown. However, over the last decades, it has become increasingly clear that Zinc finger protein A20 is considered to be a pivotal link to the inflammation throughout the whole pathological process of myocardial ischemia/reperfusion induced tissue injury (4).

Zinc finger protein A20, also described as the TNF- $\alpha$ induced protein 3 (TNFAIP3), is a widely expressed cytoplasmic signaling protein, commonly deemed as an anti-inflammatory, nuclear factor-kappa B (NF-кB) inhibitory, and anti-apoptotic molecule $(5,6)$. A20 was one key part of the mechanisms involved in multiple autoimmune and inflammatory diseases, such as coronary artery disease, psoriasis, systemic sclerosis, coeliac disease, type 1 diabetes, inflammatory bowel disease, and rheumatoid arthritis. A20 comprehensively results in alterations to the signaling pathways leading to inflammatory changes, and in consequence, regulates the intensity and duration of signaling by several critical factors mainly dependent on NF- $\kappa$ B pathway (7). And, we have also reported that up-regulating A20 could protect blood brain barrier against ischemic stroke superimposed on systemic inflammatory challenges (8). However, no data have been published focused on the role of A20 in pathogenesis of MI/RI.

Moreover, an increasing body of evidence suggested that $I / R$ could elevate the activation of NF- $\mathrm{B}$, whereas inflammatory response was inhibited after NF- $\kappa \mathrm{B}$ deactivation, and cardiac function restored. IкB- $\alpha$, regarded as an inhibitor, binds to NF$\kappa \mathrm{B}$ p65/p50 heterodimer in cytoplasm (9-11). Phosphorylation and subsequent degradation of IКB- $\alpha$ caused by IKK- $\beta$ activation lead to the release of $\mathrm{NF}-\kappa \mathrm{B}$ and then translocation to nucleus. Ultimately, that will stimulate the production of various inflammatory cytokines, such as interleukin (IL)-1 $\beta$, tumor necrosis factor (TNF)- $\alpha$, IL- 6 and cell adhesion molecules which acts directly or indirectly to depress cardiac function (12). Meanwhile, PMNs infiltration also remarkably influences the post-ischemic perfused myocardium and various metabolites into the myocardial cells as well. Therefore, suppressing PMNs infiltration and NF- $\kappa \mathrm{B}$ activation can obviously alleviate MI/RI induced damages and consequently offer myocardial protection $(13,14)$.

Ginkgolide B (GB, Figure 1), an effective flavonoid monomer, was extracted from Ginkgo biloba leaves with multiple modulatory or protective functions and has been used in the treatment of cardio-cerebral vascular system damage for years (15-17). Most recently, researchers have discovered that GB could exert modulatory or protective functions against inflammatory reactions induced cascade effect to subsequently

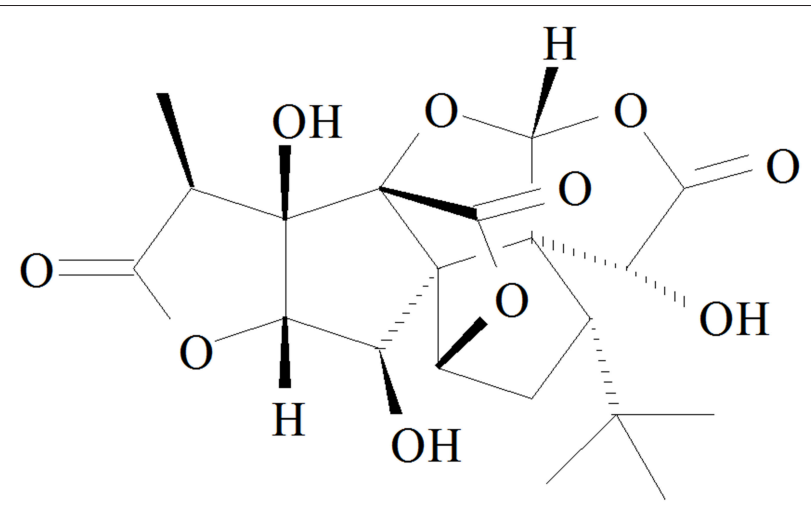

FIGURE 1 | Chemical structure of GB.

alleviate ischemia reperfusion diseases $(18,19)$. Moreover, there has been reported that GB could protect against IR-induced myocardial dysfunction and degradation of the membrane phospholipids (20). However, there has been no research reported on the relations between $\mathrm{A} 20$ and $\mathrm{GB}$, meanwhile the specific mechanism of its anti-inflammatory effects is still limited and need an in-depth elucidation.

Thus, in this study, we investigated the role of GB in the protection of inflammation induced by MI/RI in vivo. We also made positive efforts to elucidate the role of $A 20-N F-\kappa B$ signal pathway in the protection of ventricular myocytes exposed to $\mathrm{H} / \mathrm{R}$ in vitro.

\section{MATERIALS AND METHODS}

\section{Materials and Reagents}

GB (PubChem CID: 65243), 2, 3, 5-Triphenyltetrazolium chloride (TTC) was purchased from Sigma (St. Louis, MO, United States). DMEM medium (high glucose) and newborn calf serum were purchased from Gibco (Grand Island, NY, United States). TNF- $\alpha$, IL-1 $\beta$, and IL-6 ELISA kits were products of Sigma (St. Louis, MO, United States). Anti-A20, anti-ICAM-1, anti-VCAM-1, anti-iNOS, anti-NF-кB p65, anti-p-ІкB- $\alpha$, antiIKK- $\beta$, anti-Histone, anti- $\beta$-actin, goat anti-rabbit and antimouse IgG antibodies were products of Santa Cruz (Santa Cruz, CA, United States). Enhanced chemiluminescence (ECL) plus kit was product of Keygen Biotech.

\section{Animals}

Male Sprague-Dawley rats (250-300g, Experimental Animal Center of Shandong University) were used for the current study. A20 gene silencing male mouse strains were provided by Beijing Biocytogen Co., Ltd. Rats and mice were housed in a temperature-controlled environment $\left(18-22^{\circ} \mathrm{C}\right)$ with a $12 \mathrm{~h}$ light-dark cycle and allowed free access to food and water before the experiment. All the experiments were approved by the ethics committee of the Shandong Provincial Hospital affiliated to Shandong University (NSFC: No. 2018-019). 


\section{In vivo I/R Procedure to Induce $\mathrm{MI} / \mathrm{RI}$ in Rats}

I/R surgery was exactly carried out in accordance with the procedure in Figure 2A. The rats were anesthetized with $300 \mathrm{mg} / \mathrm{kg}$ chloral hydrate (i.p.). Electrocardiograph was continuously applied to monitor the changes of S-T segment so as to determine the success of surgery. After a left thoracotomy, the left anterior descending (LAD) coronary artery was twined with a plastic tube by a 6-0 silk suture for reversible LAD occlusion. Reperfusion for $120 \mathrm{~min}$ was initiated by releasing the suture and removing the tension after transient regional myocardial ischemia for $40 \mathrm{~min}$ according to the procedure. Before the rats were sacrificed, the blood samples were collected.

Randomly selected rats were divided into 5 groups as follows ( $n=8$ per group): (1) Control group, rats did not receive $\mathrm{I} / \mathrm{R}$, saline was administered; (2) I/R group, I/R rats administered with saline; (3) $8 \mathrm{mg} / \mathrm{kg}$ GB group, I/R rats received $8 \mathrm{mg} / \mathrm{kg}$ of GB; (4) $16 \mathrm{mg} / \mathrm{kg}$ GB group, I/R rats received $16 \mathrm{mg} / \mathrm{kg}$ of GB; (5) 32 $\mathrm{mg} / \mathrm{kg} \mathrm{GB}$ group, I/R rats received $32 \mathrm{mg} / \mathrm{kg}$ of GB. Saline and

A
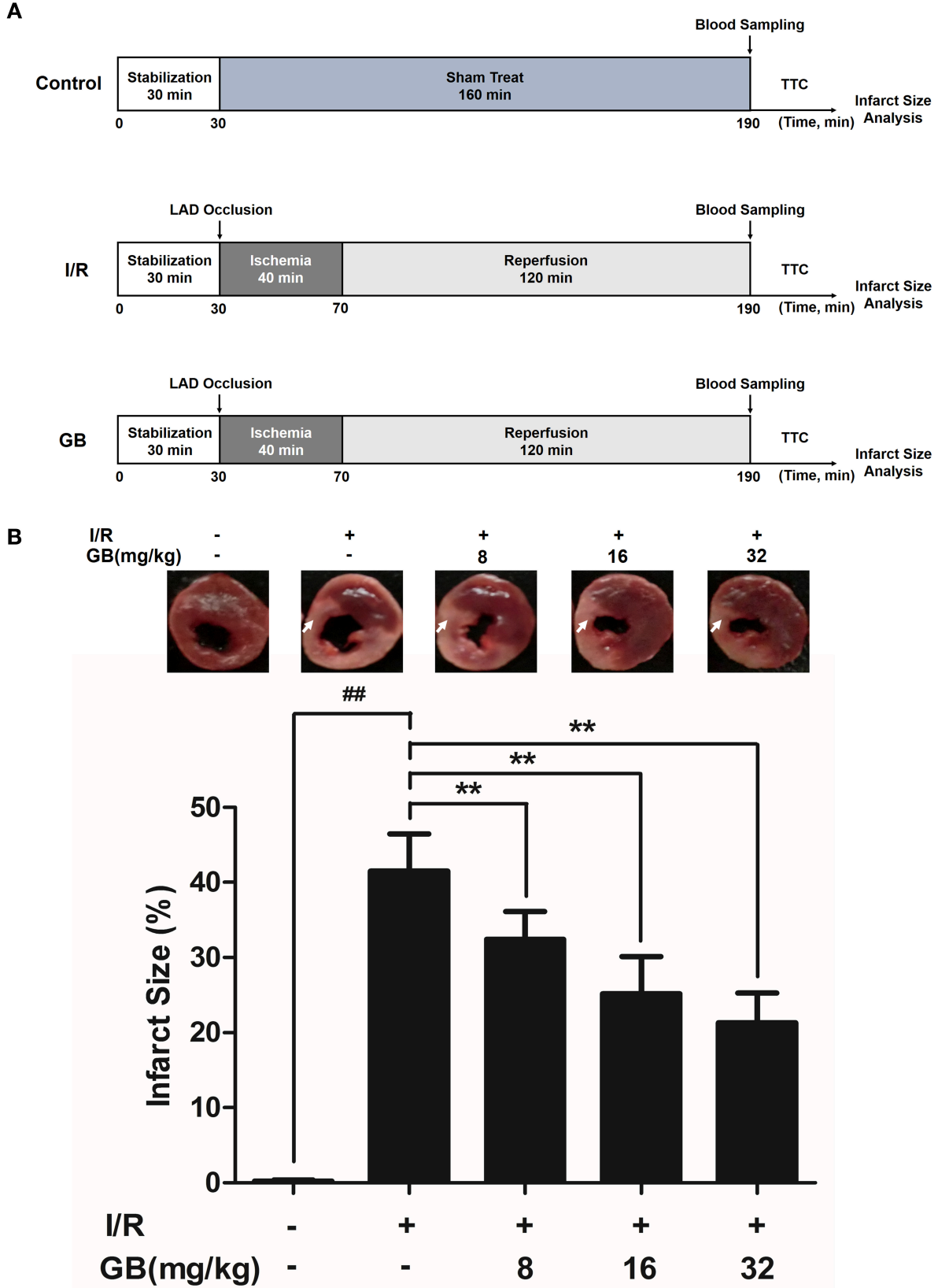

FIGURE 2 | Effects of GB on infarct size in MI/RI rats model. (A) The experimental procedures of in vivo MI/RI rats model. (B) Treatment with GB significantly reduced the infarct size in Ml/RI rats model. Data were expressed as mean \pm S.D. $(n=8)$. ${ }^{\# \# ~} P<0.01, \mathrm{l} / \mathrm{R}$ group vs. control group; ${ }^{\star} P<0.05$, ${ }^{\star \star} P<0.01,8,16,32 \mathrm{mg} / \mathrm{kg}$ GB groups vs. I/R group. 

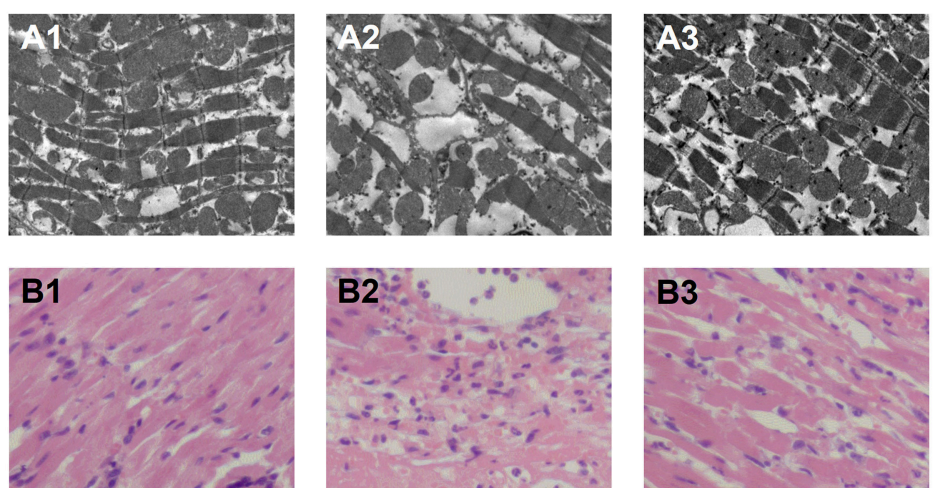

C
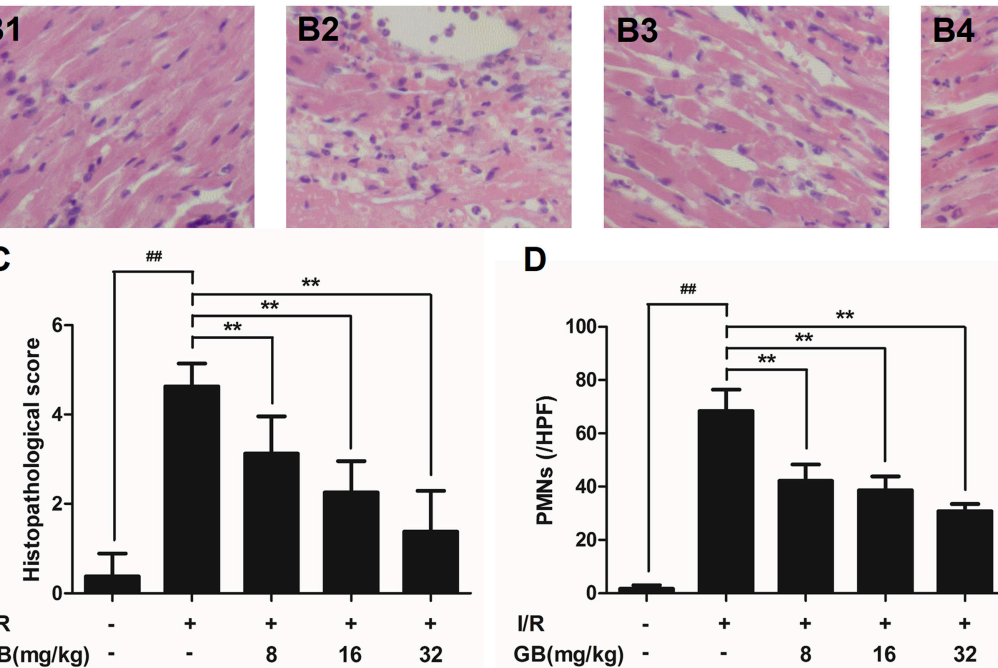

D

$\mathbf{F}$
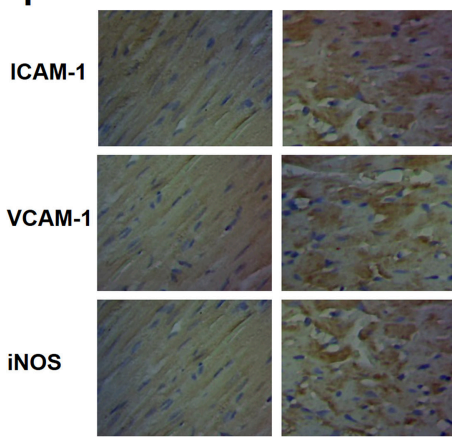

$+$

$\mathrm{GB}(\mathrm{mg} / \mathrm{kg})$ -

$\mathbf{G}$

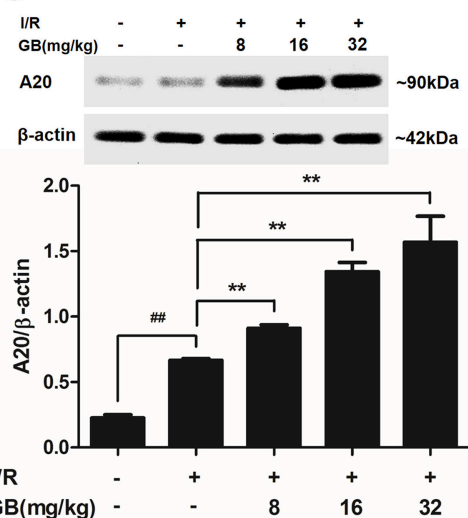

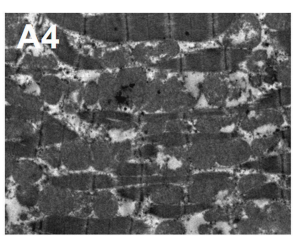
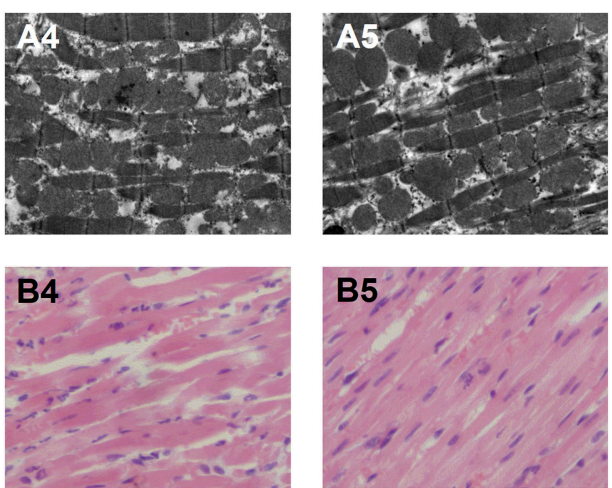

E

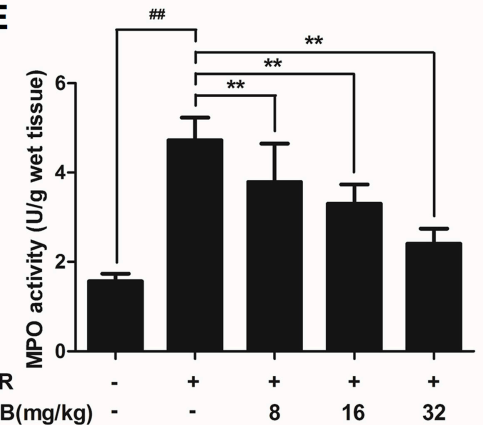

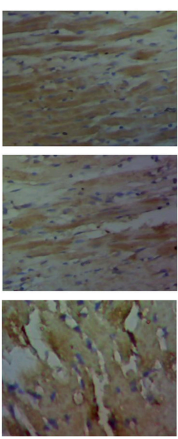
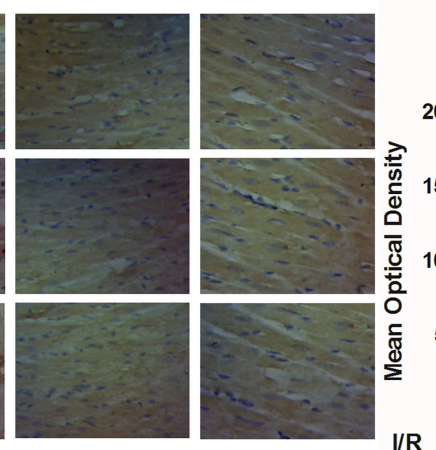

ICAM-1 VCAM-1 iNOS

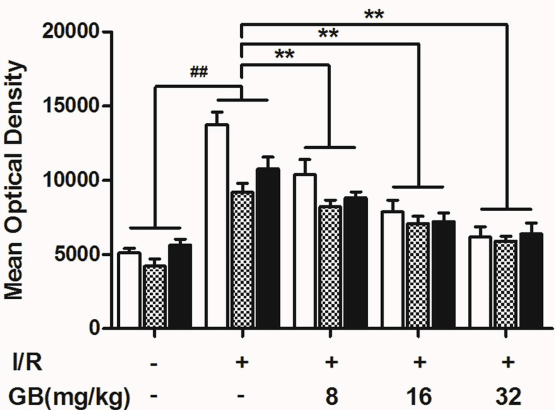

FIGURE 3 | Effects of GB on the ultrastructure of myocardial tissue, histopathological changes, histopathological scores, PMNs counting, MPO activity and ICAM-1, VCAM-1, iNOS expressions in MI/RI rats model. (A1-5) Representative transmission electron microscopy (TEM) observation of myocardial tissue injury for control group (A1), l/R group (A2), l/R $+8 \mathrm{mg} / \mathrm{kg}$ GB group (A3), l/R $+16 \mathrm{mg} / \mathrm{kg}$ GB group (A4), l/R $+32 \mathrm{mg} / \mathrm{kg}$ GB group (A5). (B1-5) Representative light microscopic 
FIGURE 3 | appearance of rat myocardial histopathological morphology (HE staining; original magnification $\times 200$ ) for control group (B1), I/R group (B2), I/R + 8 $\mathrm{mg} / \mathrm{kg}$ GB group (B3), l/R $+16 \mathrm{mg} / \mathrm{kg}$ GB group (B4), l/R $+32 \mathrm{mg} / \mathrm{kg}$ GB group (B5). (C) Effect of GB on histopathological scores, (D) effect of GB on myocardial PMNs counting, (E) effect of GB on MPO activity, effect of GB on expressions of ICAM-1, VCAM-1, iNOS (F) and effect of GB on expression of A20 (G). The location of the histological images were taken in three random fields of infarcted area. Data were expressed as mean \pm S.D. $(n=8)$. $\# \# P<0.01$, l/R group vs. control group; ${ }^{\star} P<0.05,{ }^{\star \star} P<0.01,8,16,32 \mathrm{mg} / \mathrm{kg}$ GB groups vs. I/R group.

GB were, respectively administered intraperitoneally for 7 days before cardiac I/R operation.

\section{In vivo I/R Procedure to Induce $\mathrm{MI} / \mathrm{RI}$ in A20 Gene Silencing Mice}

I/R surgery was exactly carried out in accordance with the procedure in Figure 5A. The mice were anesthetized with 60 $\mathrm{mg} / \mathrm{kg} 3 \%$ sodium pentobarbital (i.p.). Electrocardiograph was continuously applied to monitor the changes of S-T segment so as to determine the success of surgery. A longitudinal incision was made at the left margin of the sternum $2 \sim 3 \mathrm{~mm}$ and between the second and third costal points. The intercostal artery was ligatured and the thymus and pericardium were separated to expose the heart. After a left thoracotomy, the LAD coronary artery was tied in a slipknot using a 7-0 silk suture. In sham operated mice, silk sutures were placed around LAD but were not ligated. After transient regional myocardial ischemia for $30 \mathrm{~min}$, unlock slipknot, the blood flow of the coronary artery was recovered for $90 \mathrm{~min}$. Before the rats were sacrificed, the blood samples were collected.

Randomly selected mice were divided into 5 groups as follows ( $n=8$ per group): (1) Control group, A20 gene silencing mice did not receive I/R, saline was administered; (2) I/R group, I/R A20 gene silencing mice administered with saline; (3) $12 \mathrm{mg} / \mathrm{kg}$ GB group, I/R A20 gene silencing mice received $12 \mathrm{mg} / \mathrm{kg}$ of GB; (4) $24 \mathrm{mg} / \mathrm{kg}$ GB group, I/R A20 gene silencing mice received 24 $\mathrm{mg} / \mathrm{kg}$ of GB; (5) $48 \mathrm{mg} / \mathrm{kg}$ GB group, I/R A20 gene silencing mice received $48 \mathrm{mg} / \mathrm{kg}$ of GB. Saline and GB were, respectively administered intraperitoneally for 7 days before cardiac $I / R$ operation.

\section{Measurement of Infarct Size}

Infarct size was determined by TTC staining technique. After $\mathrm{I} / \mathrm{R}$ procedure, the hearts were excised and frozen at $-80^{\circ} \mathrm{C}$ for $4 \mathrm{~h}$. The left ventricle area of heart was cut into five $2-3 \mathrm{~mm}$ thick slices from the apex to the base. After incubation in $2 \%$ TTC in PBS ( $\mathrm{pH} 7.4)$ solution for $15 \mathrm{~min}\left(37^{\circ} \mathrm{C}\right)$, the third slice was immersed in formalin (4\%) for another $30 \mathrm{~min}$. Then, the area of the infarcted tissues was photographed with a digital camera and measured by Image-Pro Plus software (version 6.0, Media Cybernetic, United States) according to computerized planimetry. Infarct size was expressed as the percentage of infarcted area to the risk region $\times 100 \%$.

\section{Transmission Electron Microscopy}

The third heart slice was fixed in 3.0\%, pH 7.2 glutaraldehyde buffered fixative for 2-3 days. Then the specimens were embedded in Polybed 812 before being rinsed in PBS. 60-80 $\mathrm{nm}$-thick specimens were analyzed with a transmission electron microscope (JEM-2000EX) in three random fields.

\section{Histopathological Examination and Analysis of PMNS Infiltration Intensity}

The third heart slice was stained with hematoxylin-eosin (H\&E) and analyzed by light microscopy in three random fields. The intensity of histopathological damage was evaluated via pathological scores in accordance with the criteria reported by the previous study (21): (1) score 0: no damage; (2) score 1: mild damage; (3) score 2: moderate damage; (4) score 3: severe damage; (5) score 4: highly severe damage. The mean of the absolute number of PMNs was also recorded in three random high-power fields (HPF).

\section{Immunohistochemistry}

Immunohistochemistry was applied to evaluate the expressions of ICAM-1, VCAM-1, and iNOS. The third heart slice was frozen and blocked by $10 \%$ normal serum. And, anti-ICAM-1, antiVCAM-1 and anti-iNOS antibodies were incubated overnight at $4^{\circ} \mathrm{C}$ after being. Then, the heart slice was incubated with antirabbit IgG primary antibody for $30 \mathrm{~min}$. Immunohisochemical staining protocol was used for further immunohistological analysis under the fluorescence microscope in three random fields. Image-Pro Plus software (version 6.0) was applied to quantify the optical density of positive staining area, as described previously (22). The results were expressed as mean optical density mean \pm S.D.

\section{MPO Activity Assay}

The ischemic tissue samples were homogenized and sonicated to release the MPO into the supernatant. Then, the activity of MPO was measured using kits according to the manufacture instructions (AmyJet Scientific Inc., Wuhan, China).

\section{In vitro H/R Procedure to Induce H/R Injury in Ventricular Myocytes}

Rat ventricular myocytes were separated from the hearts of 14-day-old Sprague-Dawley rats according to trypsin enzymic digestion and differential attachment methods as described previously (21). Three days later, the cells were finally purified at a density of $1 \times 10^{5} / \mathrm{mL}$ in DMEM medium supplemented with $10 \%$ fetal calf serum in $95 \%$ air $/ 5 \% \mathrm{CO}_{2}$ at $37^{\circ} \mathrm{C}$.

$\mathrm{H} / \mathrm{R}$ treatment procedure (Figure 4A). The cells were incubated in $95 \% \mathrm{~N}_{2} / 5 \% \mathrm{CO}_{2}$ for $2 \mathrm{~h}$ (hypoxia) and then in $95 \%$ air $/ 5 \% \mathrm{CO}_{2}$ for $2 \mathrm{~h}$ (reoxygenation). Randomly selected cells were divided into five groups as follows ( $n=8$ per group): (1) Control group, cells did not receive $\mathrm{H} / \mathrm{R}$ and were cultured in DMEM medium; (2) H/R group, cells receive H/R; (3) $1 \mu \mathrm{M}$ GB group, $\mathrm{H} / \mathrm{R}$ cells were pre-incubated with $1 \mu \mathrm{M}$ GB for $24 \mathrm{~h}$; (4) $10 \mu \mathrm{M}$ GB group, H/R cells were pre-incubated with $10 \mu \mathrm{M}$ GB for $24 \mathrm{~h}$; (5) $100 \mu \mathrm{M}$ GB group, H/R cells were pre-incubated with $100 \mu \mathrm{M}$ GB for $24 \mathrm{~h}$. 
A

Control
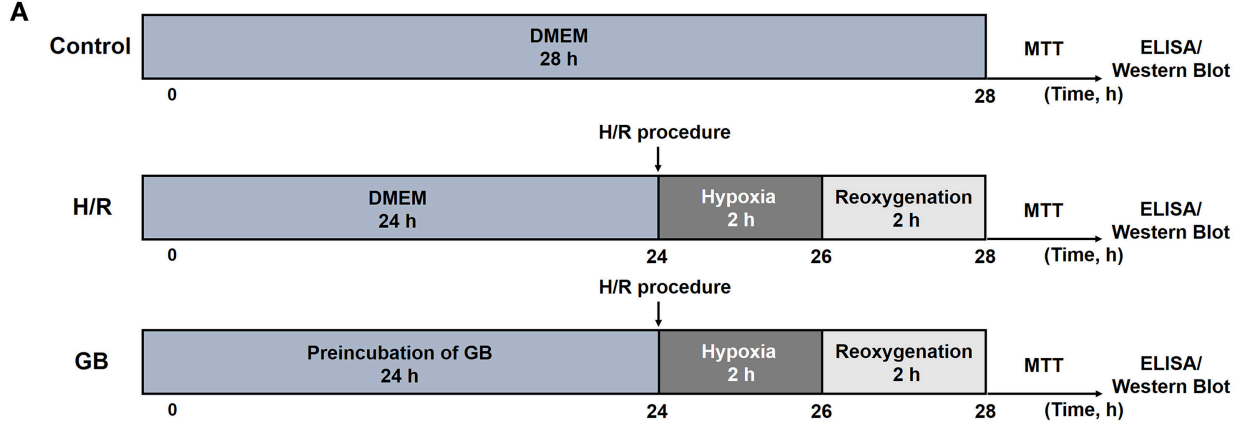

B

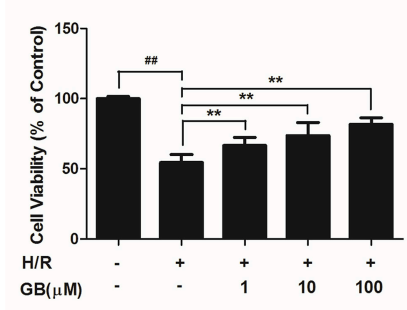

E

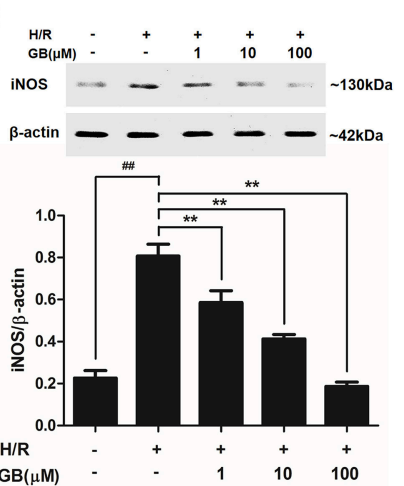

H
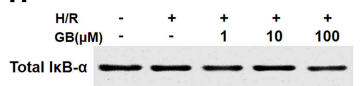

p-IKB- $\alpha$

$\beta$-actin $\longrightarrow \sim 42 \mathrm{kDa}$

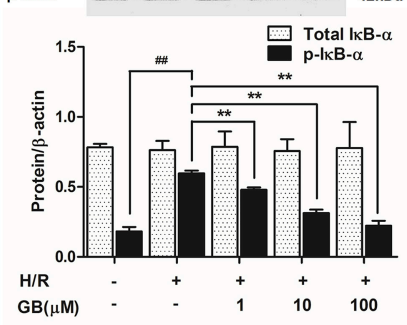

C
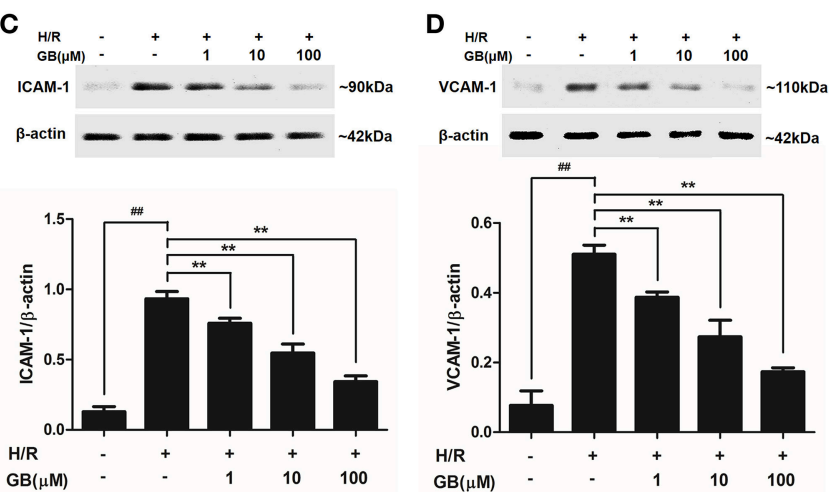

F

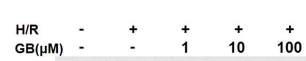

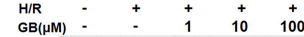
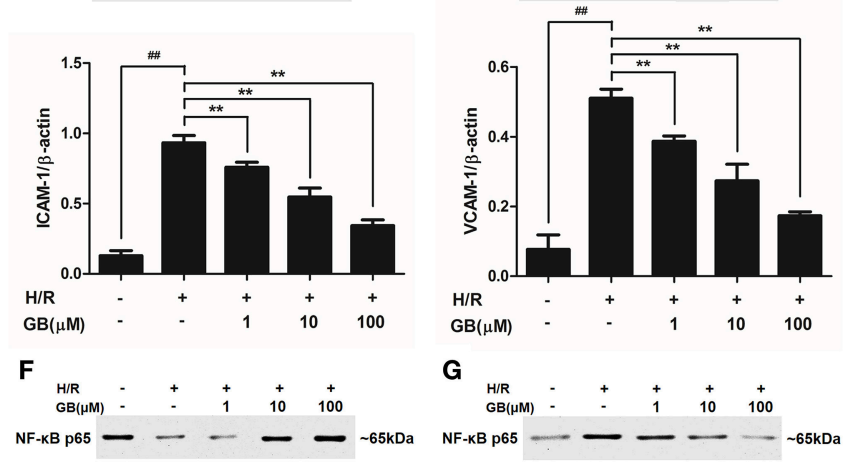

G

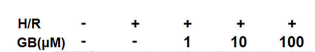

NF-KB p65 - - - - $-65 \mathrm{kDa}$
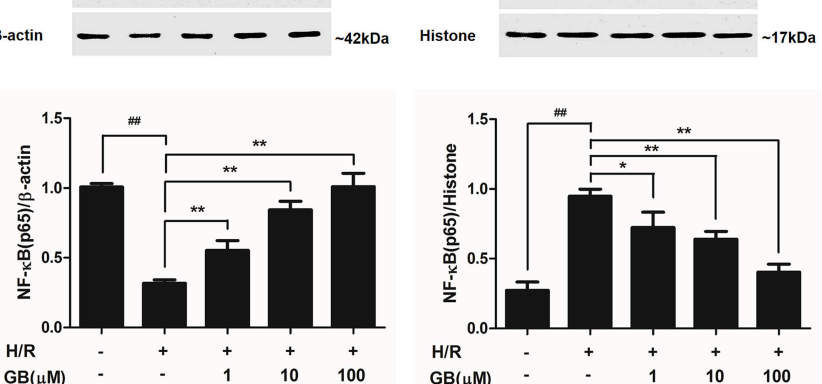

I
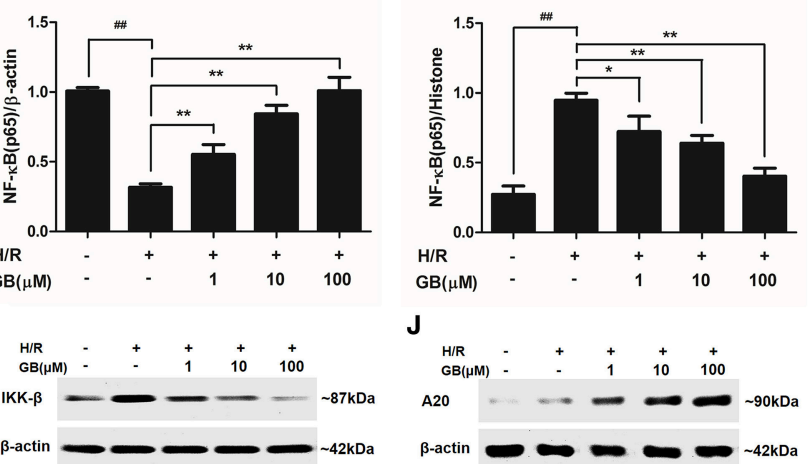

J
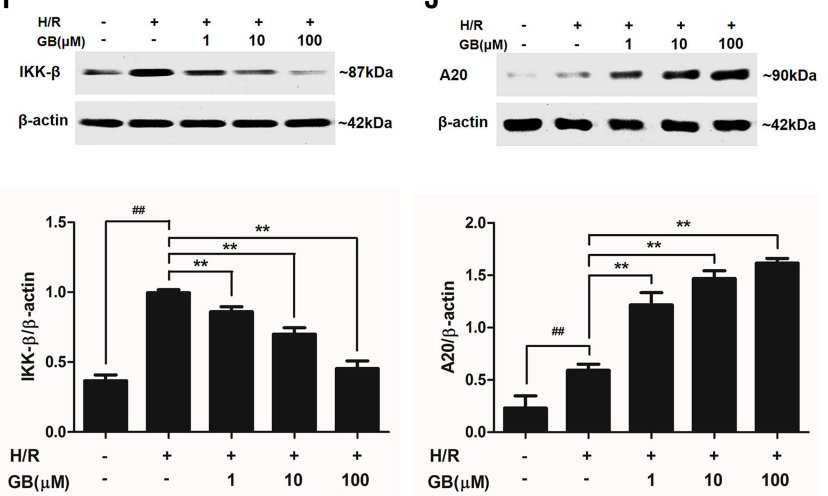

FIGURE 4 | Effects of GB on cell viability and the expressions of ICAM-1, VCAM-1, iNOS, NF-kB p65, p-IkB- $\alpha$, IKK- $\beta$ by Western blot in H/R ventricular myocytes model. (A) The experimental procedures of in vitro $\mathrm{H} / \mathrm{R}$ ventricular myocytes model. (B) GB significantly increased the cell viability after $\mathrm{H} / \mathrm{R}$ procedure. (C) $\mathrm{GB}$ decreased the expression of ICAM-1. (D) GB decreased the expression of VCAM-1. (E) GB decreased the expression of iNOS. GB blocked the translocation of NF-kB p65 from cytosolic (F) to nuclear (G). (H) GB down-regulated the expression of p-IкB- $\alpha$. (I) GB decreased the expression of IKK- $\beta$. (J) GB increased the expression of A20. The NF-KB p65 protein levels were assayed separately in cytosolic (F) and nuclear (G) extracts. Results were expressed as Protein/reference protein ratio. Data were expressed as mean \pm S.D. of three independent experiments. ${ }^{\#} \# P<0.01 \mathrm{H} / \mathrm{R}$ group vs. control group; ${ }^{\star} P<0.05,{ }^{* *} P<0.01,1,10$, $100 \mu \mathrm{M}$ GB groups vs. I/R group. 

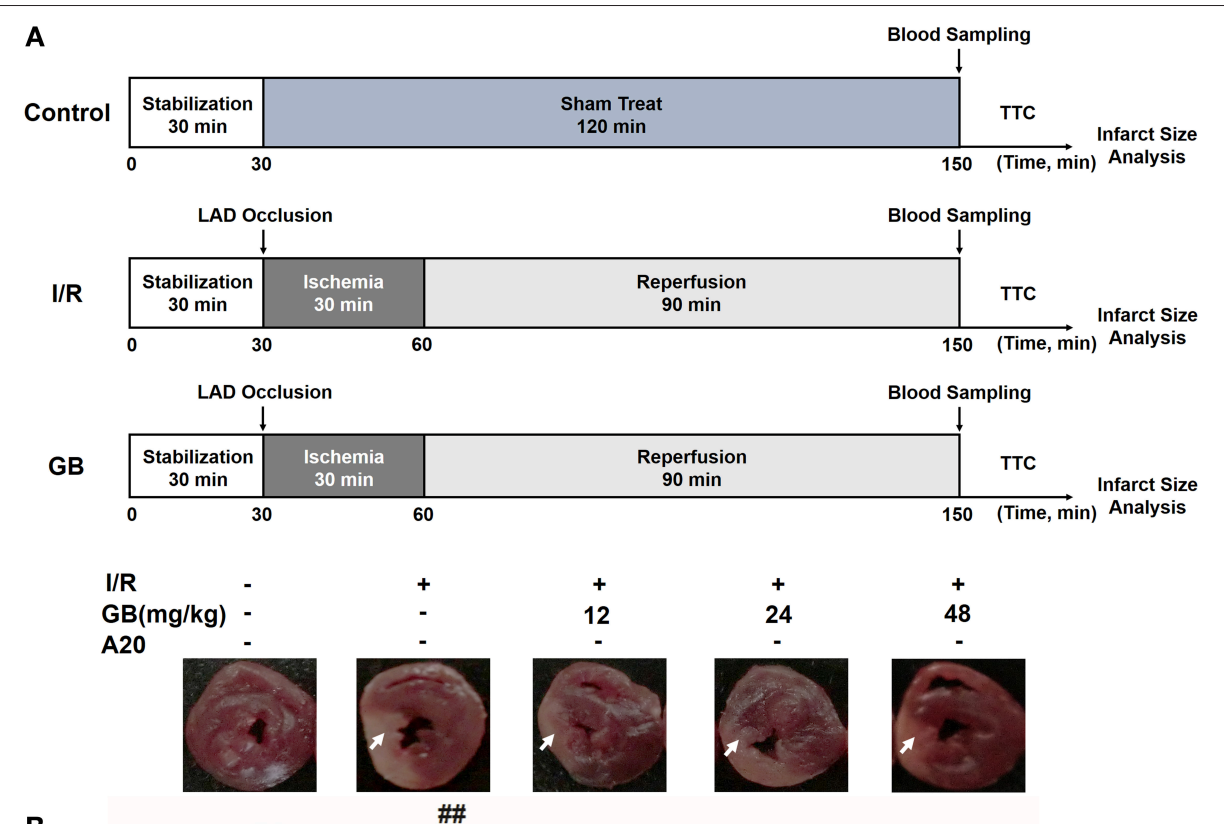

B

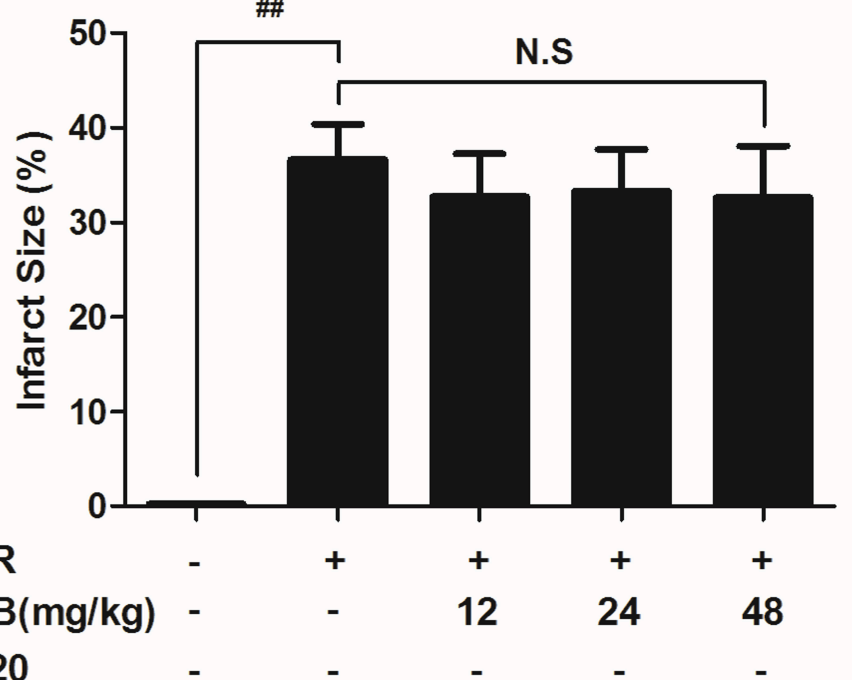

FIGURE 5 | Effects of GB on infarct size in A20 gene silencing MI/RI mice model. (A) The experimental procedures of in vivo A20 gene silencing MI/RI mice model. (B) Treatment with GB significantly reduced the infarct size in A20 gene silencing MI/RI mice model. Data were expressed as mean \pm S.D. ( $n=8$ ). $\# \# P<0.01$, I/R group vs. control group; ${ }^{\star} P<0.05,{ }^{\star \star} P<0.01,12,24,48 \mathrm{mg} / \mathrm{kg}$ GB groups vs. I/R group.

\section{Reconstruction of A20 Gene Silencing Ventricular Myocytes}

After the density of ventricular myocytes reached $1 \times 10^{5} / \mathrm{mL}$, the cells were transfected with pGPU6/Hygro in control group while pGPU6/Hygro-A20 in other groups for $24 \mathrm{~h}$ using the GenePharma Transfection Reagent. After the transfection, cells were treated with $\mathrm{H} / \mathrm{R}$.

\section{In vitro H/R Procedure to Induce H/R Injury} in A20 Gene Silencing Ventricular Myocytes

The A20 gene silencing cells were incubated in 95\% $\mathrm{N}_{2} / 5 \%$ $\mathrm{CO}_{2}$ for $2 \mathrm{~h}$ (hypoxia) and then in $95 \%$ air $/ 5 \% \mathrm{CO}_{2}$ for $2 \mathrm{~h}$ (reoxygenation). Randomly selected cells were divided into 5 groups as follows ( $n=8$ per group): (1) Control group, cells did not receive H/R and were cultured in DMEM medium; (2) H/R group, A20 gene silencing cells receive H/R; (3) $1 \mu \mathrm{M}$ GB group, $\mathrm{H} / \mathrm{R}$ A20 gene silencing cells were pre-incubated with $1 \mu \mathrm{M}$ GB for $24 \mathrm{~h}$; (4) $10 \mu \mathrm{M}$ GB group, H/R A20 gene silencing cells were pre-incubated with $10 \mu \mathrm{M}$ GB for $24 \mathrm{~h}$; (5) $100 \mu \mathrm{M}$ GB group, $\mathrm{H} / \mathrm{R}$ A20 gene silencing cells were preincubated with $100 \mu \mathrm{M}$ GB for $24 \mathrm{~h}$.

\section{Analysis of Cell Vitality}

Cell viability of ventricular myocytes was quantified with 3-(4,5dimethylthiazol-2-yl)-2,5-diphenyl tetrazolium bromide (MTT) colorimetric assay. At the end of $H / R$ procedure, cells were 
TABLE 1 | Effects of GB on serum inflammatory cytokines in MI/RI rats model.

\begin{tabular}{lcccc}
\hline Group & $\begin{array}{c}\text { Dose } \\
(\mathbf{m g} / \mathbf{k g})\end{array}$ & TNF- $\alpha$ (pg/mL) & IL-1 $\boldsymbol{\beta}(\mathbf{p g} / \mathbf{m L})$ & IL-6 $(\mathbf{p g} / \mathbf{m L})$ \\
\hline Control & & $13.63 \pm 3.61$ & $56.41 \pm 12.19$ & $31.94 \pm 8.34$ \\
I/R & & $86.34 \pm 15.40^{\# \#}$ & $239.56 \pm 17.38^{\# \#}$ & $103.78 \pm 10.45^{\# \#}$ \\
I/R+GB & 8 & $66.34 \pm 10.98^{\star \star}$ & $185.65 \pm 21.76^{\star \star}$ & $90.13 \pm 14.53^{\star}$ \\
& 16 & $48.54 \pm 8.07^{\star \star}$ & $133.49 \pm 23.68^{\star \star}$ & $62.34 \pm 8.31^{\star \star}$ \\
& 32 & $27.39 \pm 6.31^{\star \star}$ & $85.68 \pm 9.78^{\star \star}$ & $50.49 \pm 3.98^{\star \star}$
\end{tabular}

Values were expressed as mean $\pm S D(n=8)$.

${ }^{\# \#} P<0.01$ I/R group vs. control group; ${ }^{*} P<0.05,{ }^{* \star} P<0.01,8,16,32 \mathrm{mg} / \mathrm{kg}$ GB groups vs. I/R group.

TABLE 2 | Effects of GB on supernatant inflammatory cytokines in $H / R$ ventricular myocytes model.

\begin{tabular}{|c|c|c|c|c|}
\hline Group & $\begin{array}{c}\text { Concentration } \\
(\mu \mathrm{M})\end{array}$ & $\begin{array}{l}\text { TNF- } \alpha \\
\text { (pg/mL) }\end{array}$ & $\begin{array}{c}\text { IL-1 } \beta \\
\text { (pg/mL) }\end{array}$ & IL-6 (pg/mL) \\
\hline Control & & $5.21 \pm 2.16$ & $87.29 \pm 6.89$ & $23.10 \pm 3.15$ \\
\hline$H / R$ & & $62.17 \pm 5.96^{\# \#}$ & $875.09 \pm 47.10^{\# \#}$ & $681.34 \pm 29.32^{\# \#}$ \\
\hline \multirow[t]{3}{*}{$\mathrm{H} / \mathrm{R}+\mathrm{GB}$} & 1 & $43.26 \pm 10.11^{\star \star}$ & $529.21 \pm 43.43^{\star \star}$ & $501.21 \pm 22.31^{* *}$ \\
\hline & 10 & $32.18 \pm 2.98^{\star \star}$ & $329.11 \pm 20.98^{* *}$ & $209.34 \pm 13.34^{* *}$ \\
\hline & 100 & $16.88 \pm 2.16^{\star \star}$ & $192.10 \pm 40.19^{* \star}$ & $102.09 \pm 21.08^{\star *}$ \\
\hline
\end{tabular}

Values were expressed as mean $\pm S D(n=8)$.

${ }^{\# \#} P<0.01 \mathrm{H} / \mathrm{R}$ group vs. control group; ${ }^{*} P<0.05$, ${ }^{\star \star} P<0.01,1,10,100 \mu \mathrm{M}$ GB groups vs. I/R group.

incubated with $5 \mathrm{mg} / \mathrm{mL}$ MTT for $4 \mathrm{~h}$ at $37^{\circ} \mathrm{C}$ and the insoluble formazan crystals were dissolved in $100 \mu \mathrm{l}$ of DMSO for $15 \mathrm{~min}$. Results were expressed as percentage of the optical density (OD) at $490 \mathrm{~nm}$ measured in control cells.

\section{Measurement of TNF- $\alpha, \mathrm{II}-1 \beta$, and II-6}

Before rats and mice were sacrificed, the blood samples were obtained. After $\mathrm{H} / \mathrm{R}$ procedure, the cell supernatant was collected from medium. The expressions of TNF- $\alpha$, IL- $1 \beta$, and IL- 6 were determined via ELISA kits both in blood samples and cell supernatant.

\section{Extraction of Myocardial Tissues Protein}

RIPA Lysis Buffer (Beyotime Inc., China) and 1\% phenylmethanesulfonyl fluoride (PMSF) were used to extract the proteins in myocardial tissue. Then, the myocardial tissues were homogenized and ultrasonically ground to no precipitation. Finally, the samples were centrifuged at $12,000 \times \mathrm{g}$ at $4^{\circ} \mathrm{C}$ for $30 \mathrm{~min}$ and the total protein was collected from the supernatant. All the steps above were carried out on the ice in order to avoid protein denaturation.

\section{Western Blot Analysis}

Nuclear and Cytoplasmic Protein Extraction Kit (Beyotime Biotechnology, Beijing, China) was applied to extract the cytoplasmic and nuclear proteins from cells according to the manufacturer's instruction as described previously (21). The protein concentrations were determined by BCA assay.
Protein samples $(50 \mu \mathrm{g})$ was loaded to SDS-PAGE gel, and then transferred to a PVDF membrane at $20 \mathrm{~V}$ and $100 \mathrm{~mA}$ overnight. The membranes were blocked with 5\% skim milk, and then incubated with primary antibodies (1:800) against CD40, ICAM-1, VCAM-1, iNOS, NF-кB p65, p-IкB- $\alpha$, and IKK- $\beta$ proteins for $4 \mathrm{~h}$ at $37^{\circ} \mathrm{C}$. The horseradish peroxidaseconjugated secondary antibody $(1: 1,000)$ was added and detected using an ECL plus kit. Protein expression levels were determined by quantitating protein band densities of images taken by Gel Imaging System using Quantity One software.

\section{Statistical Analysis}

The results were expressed as the mean \pm S.E.M. Significance of difference between groups were compared using one-way analysis of variance (ANOVA) followed by Bonferroni correction for multiple comparisons. A probability value of $P<0.05$ was considered to be statistically significant. All statistical figures were performed using Graph Pad Prism software (Version 5.0).

\section{RESULTS}

\section{Effect of GB on MI/R-Induced Inflammatory Injury IN MI/RI Rats Model GB Reduced Infarct Size in MI/RI Rats}

As the results shown in Figure 2B, infarct size in the I/R group was $41.5 \pm 4.9 \%$ ( $P<0.01$ vs. control group), whereas 8,16 , $32 \mathrm{mg} / \mathrm{kg}$ GB decreased infarct size to $32.4 \pm 3.7 \%$, $25.2 \pm 5.0 \%$ and $21.3 \pm 4.0 \%(P<0.01)$, respectively, compared with the I/R group.

\section{GB Improved Cardiac Ultrastructural Characterization, Alleviated Pmns Infiltration, Decreased the Amount of Serum Inflammatory Cytokines and Inhibited Overexpressions of Myocardial Tissue ICAM-1, VCAM-1, and iNOS in MI/RI Rats}

In the control group, mitochondria containing cristae with high electron density are elongated and tightly aligned between myofibrils (Figure 3A1). However, in I/R group, the cardiac myofibers were disconnected and damaged, nuclear stained deeper, and the mitochondria became swelling and degeneration (Figure 3A2). In $8 \mathrm{mg} / \mathrm{kg}$ GB group, there were still some breaks and loss of mitochondrial cristae associated with loss of the mitochondrial matrix (Figure 3A3). In $16 \mathrm{mg} / \mathrm{kg} \mathrm{GB}$ group, the damaged mitochondria showed mild loss of cristae, swelling, myelin figures and membrane disruption (Figure 3A4). In 32 $\mathrm{mg} / \mathrm{kg}$ GB group, only a few swollen mitochondria was observed (Figure 3A5).

In the control group, the myocytes arranged regularly and no inflammatory cells were observed in the myocardial interstitium. After I/R procedure, the myocytes arranged irregularly, the tissue became necrotic, and a large number of inflammatory cells were observed in the myocardial interstitium accompanied by the formation of fibrotic scars. But GB could significantly improve the histological injury, characterized by regularly arranged myocytes and alleviative inflammatory infiltration (Figures 3B1-5). As demonstrated in Figure 3C, 8, 16, 32 mg/kg 

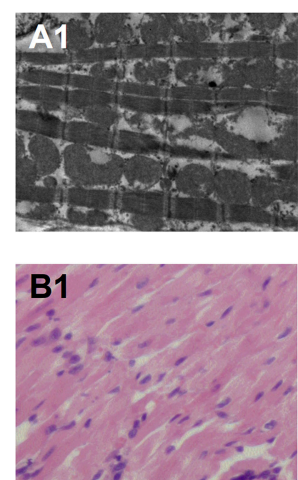

C

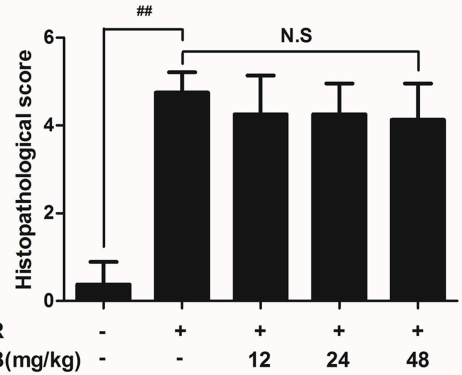

$\mathrm{GB}(\mathrm{mg} / \mathrm{kg})$

A20
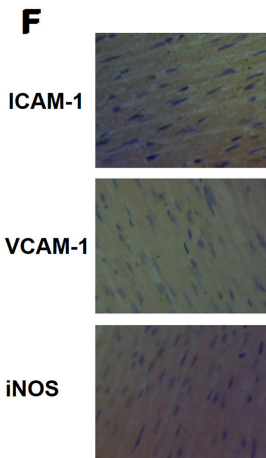

I/R

$\mathrm{GB}(\mathrm{mg} / \mathrm{kg})$ -

A20

G
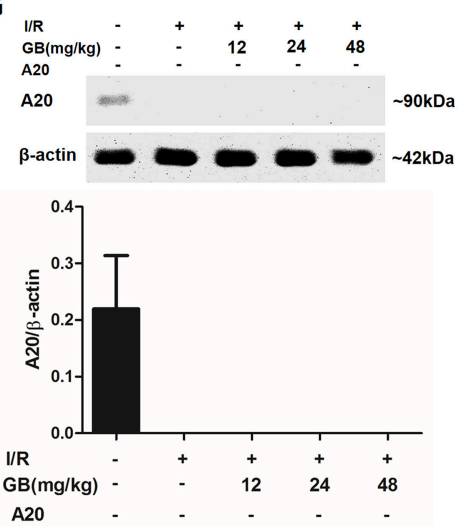
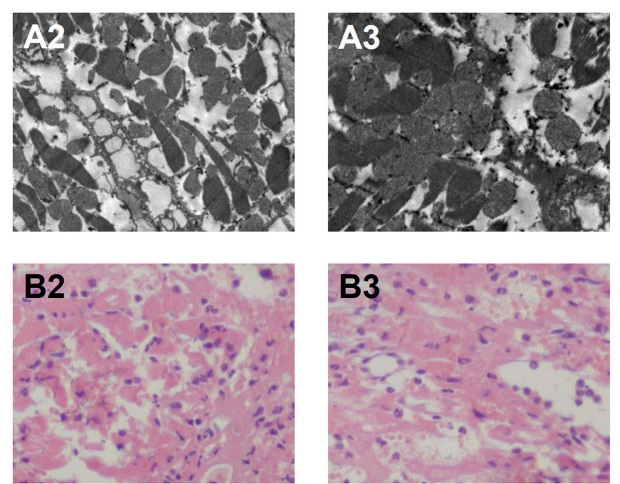

D
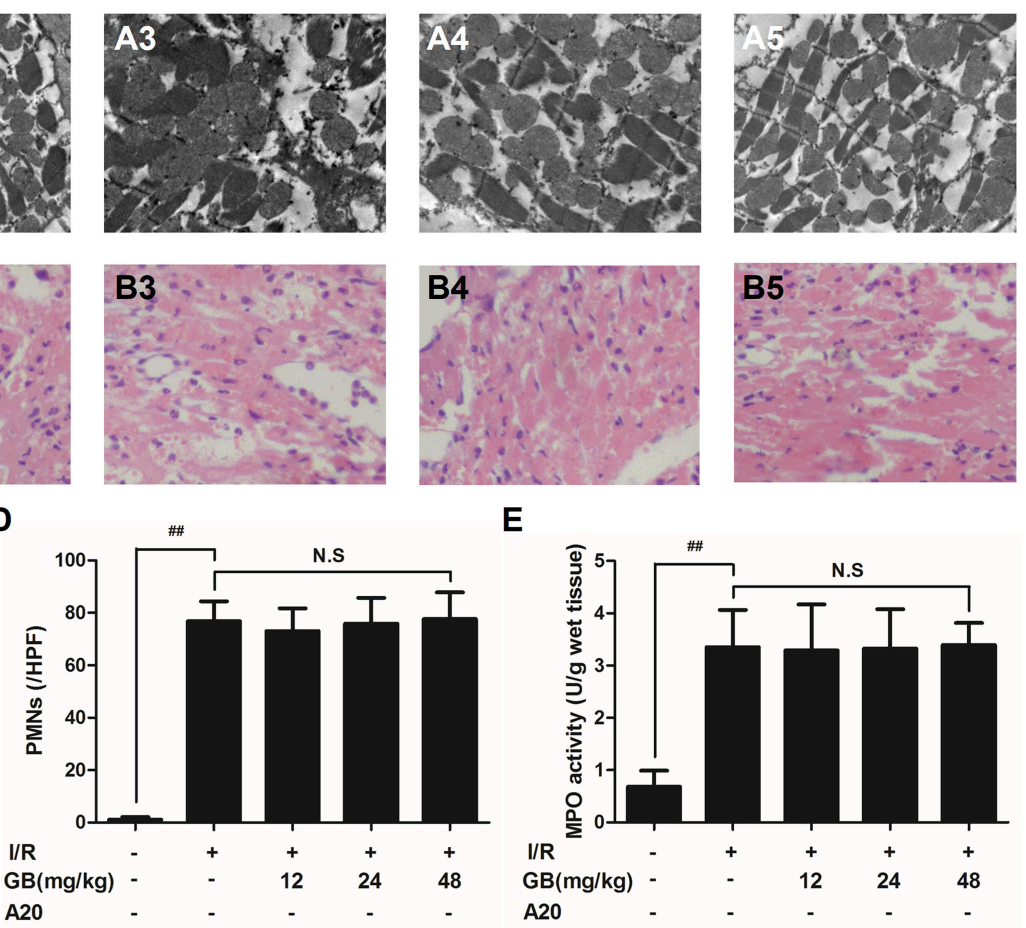

E
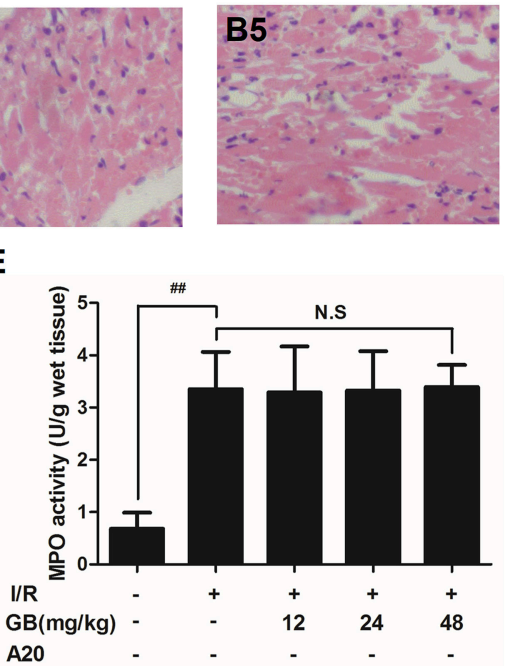

A20

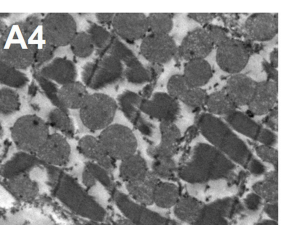

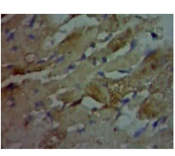
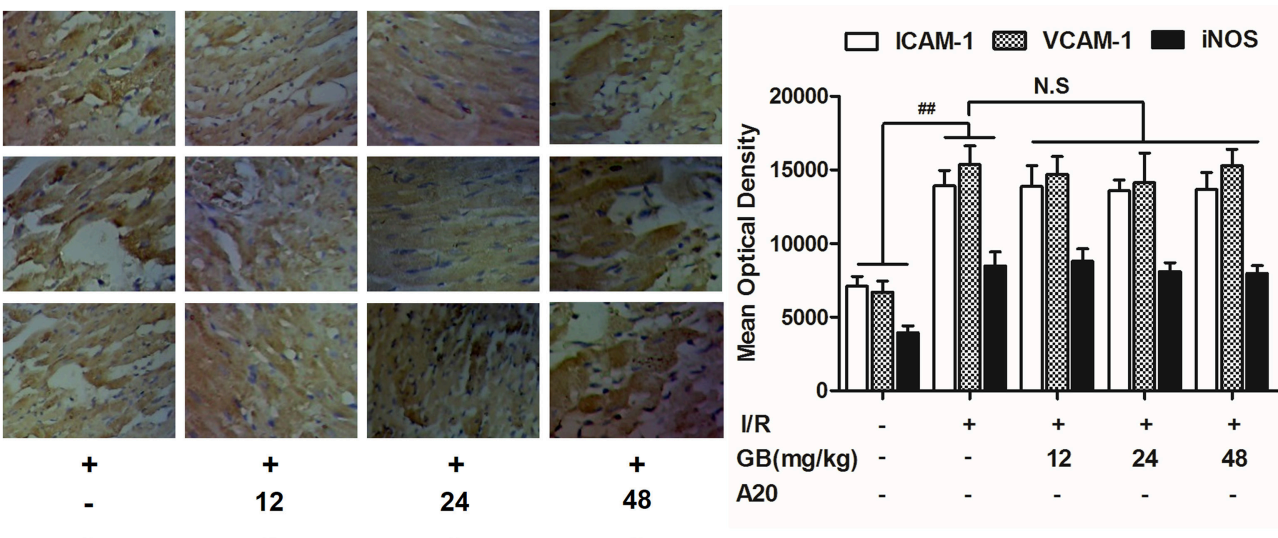

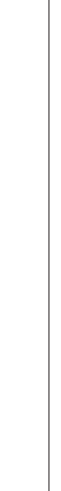


FIGURE 6 | light microscopic appearance of rat myocardial histopathological morphology (HE staining; original magnification $\times 200$ ) for control group (B1), l/R group (B2), l/R +12 mg/kg GB group (B3), l/R + 24 mg/kg GB group (B4), l/R + 48 mg/kg GB group (B5). (C) Effect of GB on histopathological scores, (D) effect of GB on myocardial PMNs counting, (E) effect of GB on MPO activity, effect of GB on expressions of ICAM-1, VCAM-1, iNOS (F) and effect of GB on expression of A20 (G). The location of the histological images were taken in three random fields of infarcted area. Data were expressed as mean \pm S.D. $(n=8)$. $\# \# P<0.01 \mathrm{I} / \mathrm{R}$ group vs. control group; ${ }^{\star} P<0.05,{ }^{* *} P<0.01,12,24,48 \mathrm{mg} / \mathrm{kg}$ GB groups vs. I/R group.

GB markedly decrease the histopathological scores compared with $\mathrm{I} / \mathrm{R}$ group $(P<0.01)$. Meanwhile, all GB groups remarkably decreased the total numbers of infiltrated and adherent PMNs compared with I/R group (Figure 3D).

Then, MPO activity was measured to evaluate the level of neutrophilic infiltration. In control group, the MPO activity was very low at $1.57 \pm 0.16 \mathrm{U} / \mathrm{g}$ protein (Figure 3E). However, the MPO activity was significantly elevated in I/R group (4.72 \pm $0.51 \mathrm{U} / g$ protein $)(P<0.01$ vs. control group). Interestingly, the current study indicated that pretreatment with GB $8 \mathrm{mg} / \mathrm{kg}(3.79$ $\pm 0.86 \mathrm{U} / \mathrm{g}$ protein, $P<0.05), 16 \mathrm{mg} / \mathrm{kg}(3.30 \pm 0.43 \mathrm{U} / \mathrm{g}$ protein, $P<0.01)$ and $32 \mathrm{mg} / \mathrm{kg}(2.40 \pm 0.33 \mathrm{U} / \mathrm{g}$ protein, $P<0.01)$ could inhibit MPO activity in myocardial tissue compared with I/R group.

As shown in Table 1, the levels of TNF- $\alpha$, IL-1 $\beta$, and IL- 6 were increased by 6.33 -fold, 4.25 -fold, and by 3.25 -fold $(P<0.01)$, respectively, compared with control group. 8, 16, $32 \mathrm{mg} / \mathrm{kg}$ GB could dose-dependently decrease the levels of TNF- $\alpha$ by $23.2 \%$ $(P<0.05), 43.8 \%(P<0.01)$ and $68.3 \%(P<0.01)$, respectively, IL-1 $\beta$ by $22.5,44.3$, and $64.2 \%(P<0.01)$, respectively, and IL6 by $13.2 \%(P<0.05), 39.9 \%(P<0.01)$ and $51.3 \%(P<0.01)$, respectively, compared with $\mathrm{I} / \mathrm{R}$ group.

As shown in Figure 3F, the expressions of ICAM-1, VCAM1 , and iNOS in I/R group were significantly elevated compared with control group. However, 8, 16, $32 \mathrm{mg} / \mathrm{kg}$ GB could effectively reduce the expressions of ICAM-1, VCAM-1 and iNOS compared with I/R group. The original pictures were put in the Supplementary Material.

\section{Gb Increased Expression of A20 in MI/RI Rats}

As shown in Figure 3G, the level of A20 in I/R group was obviously higher in contrast with control group $(P<0.01)$. But $8,16,32 \mathrm{mg} / \mathrm{kg}$ GB remarkably increased the level of A20 in response to $\mathrm{I} / \mathrm{R}$ injury ( $P<0.01$ vs. I/R group).

\section{Effect of GB on H/R-Induced Injury in H/R Ventricular Myocytes Model GB Increased Cell Viability Against H/R Injury in Ventricular Myocytes}

As shown in Figure $4 \mathrm{~B}$, the cell viability in $\mathrm{H} / \mathrm{R}$ group was markedly reduced to $54.5 \pm 5.6 \%$ ( $P<0.01$ vs. control group). $1,10,100 \mu \mathrm{M}$ GB could significantly increase the viability of cells received $\mathrm{H} / \mathrm{R}$ injury $(66.6 \pm 5.8,73.6 \pm 9.3,81.8 \pm 4.7 \%, P<0.01$ vs. H/R group).

\section{GB Inhibited Overproduction of Inflammatory Cytokines in H/R Ventricular Myocytes}

The productions of TNF- $\alpha$, IL- $1 \beta$, and IL- 6 in $H / R$ group were markedly increased by 11.93-, 10.03-, and 29.50-fold, respectively, compared with control group $(P<0.01)$ in Table 2. Pretreatment with $1,10,100 \mu \mathrm{M}$ GB could significantly reduce the levels of TNF- $\alpha$ by $30.4,48.2$, and $72.8 \%(P<0.01)$, IL-1 $\beta$ by $39.5,62.4$, and $78.0 \%(P<0.01)$, IL-6 by $26.4,69.3$, and $85.0 \%(P$ $<0.01$ ), respectively, compared with $\mathrm{H} / \mathrm{R}$ group.

\section{GB Prevented Overexpressions of ICAM-1, VCAM-1 and iNOS, Translocation of NF-кB p65, Phosphorylation of IKB- $\alpha$, Activity of IKK- $\beta$ and Increased Expression of A20 in H/R Ventricular Myocytes}

Compared with control group, the expressions of ICAM-1, VCAM-1, and iNOS markedly increased to about 7.18-, 6.65-, and 3.56-fold $(P<0.01)$ after $\mathrm{H} / \mathrm{R}$ procedure (Figures $4 \mathrm{C}-\mathrm{E}$ ). While pretreatment with $1,10,100 \mu \mathrm{M}$ GB reduced the expressions of ICAM-1 by $18.6,41.4$, and $63.2 \%(P<0.01)$, VCAM-1 by $24.2,46.4$, and $66.0 \%(P<0.01)$ and iNOS by 27.3 , 48.8, and $76.9 \%(P<0.01)$ compared with $\mathrm{H} / \mathrm{R}$ group.

As shown in Figures 4F,G, the levels of NF- $\kappa \mathrm{B}$ p65 were relatively high in the cytoplasm of cells but low in nucleus in control group. However, an evident translocation of p65 from the cytosol into nucleus showed in H/R group. Pretreatment with $1,10,100 \mu \mathrm{M}$ GB could inhibit such nuclear translocation in a concentration-dependent manner.

As shown in Figure $\mathbf{4 H}$, the total $\mathrm{I} \kappa \mathrm{B}-\alpha$ in each group was not different. Then we checked the level of $\mathrm{p}-\mathrm{I} \kappa \mathrm{B}-\alpha$ in each group. Compared with control group, the level of $\mathrm{p}-\mathrm{I} \kappa \mathrm{B}-\alpha$ in $\mathrm{H} / \mathrm{R}$ group significantly increased by 3.25 -fold $(P<0.01)$. However, $1,10,100 \mu \mathrm{M}$ GB all showed a notably inhibitory effect on phosphorylation of IкB- $\alpha$ by $19.6,47.5$, and $62.6 \%(P<0.01)$ compared with $\mathrm{H} / \mathrm{R}$ group.

And, we furtherly checked whether GB had an influence on IKK- $\beta$ activity. The results in Figure 4I showed that the level of IKK- $\beta$ significantly increased by 2.72 -fold in $H /$ R group $(P<0.01$ vs. control group). In contrast, $1,10,100 \mu \mathrm{M}$ GB could reduce the expressions of IKK- $\beta$ by $13.7,29.8$, and $54.5 \%(P<0.01)$ compared with $\mathrm{H} / \mathrm{R}$ group.

As shown in Figure 4J, there was a small increased expression of A20 after $\mathrm{H} / \mathrm{R}$ procedure $(P<0.01$ vs. control group). While pre-incubation of $\mathrm{GB}(1,10,100 \mu \mathrm{M})$ all significantly enhanced the expressions of $\mathrm{A} 20$ in response to $\mathrm{H} / \mathrm{R}$ injury $(P<0.01$ vs. H/R group).

\section{Effect of GB on MI/R-Induced Inflammatory Injury in A20 Gene Silencing MI/RI Mice Model}

In $\mathrm{I} / \mathrm{R}$ group, it was found that $\mathrm{I} / \mathrm{R}$ procedure could markedly increase infarct size (Figure 5B), destroy cardiac ultrastructural 
TABLE 3 | Effects of GB on serum inflammatory cytokines in A20 gene silencing $\mathrm{Ml} / \mathrm{Rl}$ mice model.

\begin{tabular}{|c|c|c|c|c|}
\hline Group & Dose (mg/kg) & TNF- $\alpha(p g / m L)$ & IL-1 $\beta$ (pg/mL) & IL-6 (pg/mL) \\
\hline Control & & $34.21 \pm 6.44$ & $39.53 \pm 10.98$ & $18.39 \pm 3.14$ \\
\hline I/R & & $134.31 \pm 10.98 \# \#$ & $193.53 \pm 23.67 \# \#$ & $76.55 \pm 6.98 \# \#$ \\
\hline \multirow[t]{3}{*}{$1 / R+G B$} & 12 & $119.82 \pm 14.33^{\star}$ & $153.12 \pm 17.09^{\star \star}$ & $68.05 \pm 3.29^{\star}$ \\
\hline & 24 & $87.09 \pm 5.09^{\star \star}$ & $89.31 \pm 14.13^{\star \star}$ & $52.12 \pm 6.99^{\star *}$ \\
\hline & 48 & $40.01 \pm 13.32^{\star \star}$ & $58.39 \pm 4.56^{\star \star}$ & $48.15 \pm 6.11^{\star *}$ \\
\hline
\end{tabular}

Values were expressed as mean $\pm S D(n=8)$.

${ }^{\#} P<0.01$, I/R group vs. control group; ${ }^{*} P<0.05,{ }^{*} P<0.01,12,24,48 \mathrm{mg} / \mathrm{kg} \mathrm{GB}$ groups vs. I/R group.

characterization (Figures 6A1-5), aggravate pathological changes (Figures 6B1-5C), trigger PMNs infiltration (Figure 6D), cause inflammatory cytokines overproduction (Table 3) and upregulate expressions of ICAM-1, VCAM-1, iNOS (Figure 6F). As shown in Figure 6G, there showed successful and stable A20 gene silencing in mice except the control group. It was interesting that, after A20 gene was silenced, 12, 24, $48 \mathrm{mg} / \mathrm{kg} \mathrm{GB}$ all failed to improve the outcomes induced by MI/RI (Figure 6 and Table 3).

\section{Effect of GB on H/R-Induced Injury in A20 Gene Silencing H/R Ventricular Myocytes Model GB Could Not Increase Cell Viability After A20 Gene Silencing}

The cell viabilities in $\mathrm{H} / \mathrm{R}+\mathrm{A} 20$ silencing group (Figure 7A) were significantly reduced ( $P<0.01$ vs. control group). After A20 gene silencing, GB could not elevate the cell viability against to $\mathrm{H} / \mathrm{R}$ injury.

\section{GB Could Not Inhibit the Expression of Inflammatory Factors, Translocation of NF-kB p65, Phosphorylation of IкB- $\alpha$ and Activity of IKK- $\beta$ After A20 Gene Silencing}

Compared with control group, the expressions of TNF- $\alpha$, IL$1 \beta$, IL-6, ICAM-1, VCAM-1, and iNOS in H/R + A20 silencing group were obviously increased (Table 4 and Figures 7B-D). Whereas, after A20 gene silencing, GB could not influence the expressions of TNF- $\alpha$, IL-1 $\beta$, IL-6, ICAM-1, VCAM-1, and iNOS.

The levels of NF- $\kappa \mathrm{B}$ translocation, I $\mathrm{B}-\alpha$ phosphorylation and IKK- $\beta$ activity were significantly affected in $H / R+$ A20 silence group (Figures 7E-H). Nevertheless, after A20 gene silencing, all

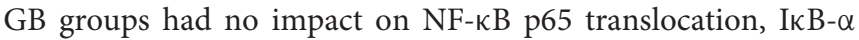
phosphorylation and IKK- $\beta$ activity compared with $\mathrm{H} / \mathrm{R}+\mathrm{A} 20$ silence group.

\section{Stable A20 Gene Silencing in Ventricular Myocytes}

As shown in Figure 7I, there was little A20 expressed after transfection by preincubation with pGPU6/Hygro in control group. In addition, the ventricular myocytes in other groups were preincubated with pGPU6/Hygro-A20 and no A20 expressed after transfection.

\section{DISCUSSION}

This is the first investigation studied on MI/RI both in vivo and in vitro to examine whether GB played a vital role in the whole pathological process of MI/RI, whether GB regulated the expression of A20 in response to H/R injury, and whether NF- $\kappa B$ signal pathway was heavily involved in the whole pathogenesis.

Inflammation is responsible for the development of many cardiovascular or cerebrovascular diseases, such as atherosclerosis, myocardial infarction, stroke, hyperlipidemia, and neurodegeneration $(23,24)$. And, it is an important form of cardiomyocyte death in the early stage of MI/RI, which further leads to severe complications such as arrhythmia and heart failure. It was traditionally believed that the process of $\mathrm{I} / \mathrm{R}$ gradually provokes severe inflammatory response and subsequent cardiac rupture, ventricular aneurysm formation, and exacerbation of left ventricular (LV) remodeling (25). However, not only the pathogenesis of I/R may lead to the inflammatory response, but inflammation itself may aggravate the $I / R$ injury. But so far, the information of molecular mechanisms underlying the proinflammatory process of MI/RI is far from certain. Therefore, study on inflammation participating in MI/RI is quite meaningful for preventive therapy.

Recently, herbal treatment of cardiovascular and cerebrovascular diseases has gained much attention. GB, a major monomer of extracts from leaves of Ginkgo biloba traditionally used in Chinese herbal medicine, displays a wide range of biological activities, including anti-inflammatory and anti-oxidant effects (26). It has been reported that GB could exert neuroprotective effects against cerebral ischemia/reperfusion injury $(\mathrm{CI} / \mathrm{RI})$ via suppressing inflammatory response and scavenging oxygen free radical $(27,28)$. Both MI/RI and $\mathrm{CI} / \mathrm{RI}$ are hypoxic and anoxic diseases, which have similar characteristics in pathogenesis and treatment, suggesting that GB may possess a potential value in the treatment strategy of MI/RI. Meanwhile, we have just proved that Ginkgolide C (GC) which possessed the similarity chemical structure to GB could exert a protective effect against MI/RI via inhibiting inflammation which might involve in blocking CD40-NF-кB signal pathway (21). However, it has not been illuminated whether GB has the similar effect of improving MI/RI yet. Consequently, in this study we investigated whether the strong anti-inflammatory property of GB constituted a part of molecular mechanisms of $\mathrm{MI} / \mathrm{RI}$ protective effect.

It is well established that infarct size is a very important indicator reflecting therapeutic effect of MI/RI. One of the most effective strategy for reducing the size followed by acute myocardial infarction is the early and successful myocardial reperfusion which can improve the clinical outcome to a great degree (29). In this study, we found that pretreatment of GB for 7 days could remarkably protect against the I/R insult through significant reduction of infarct size. In addition, we found that GB largely improves myocardium damage as evidenced by restoration of myocardial ultrastructure and suppression of myofibrillar degeneration.

PMNs, which are involved in multiple non-infectious inflammatory processes including the response to MI/RI, serves 


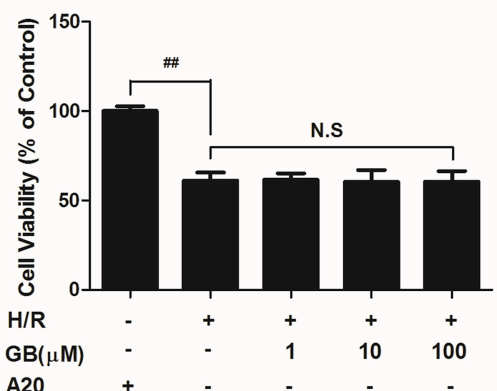

D
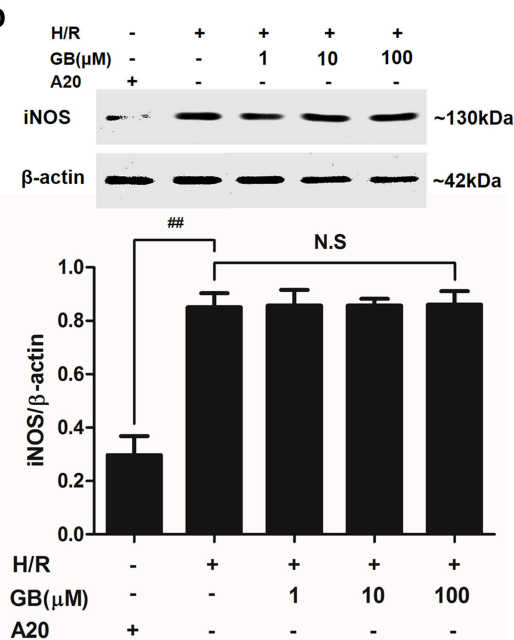

G
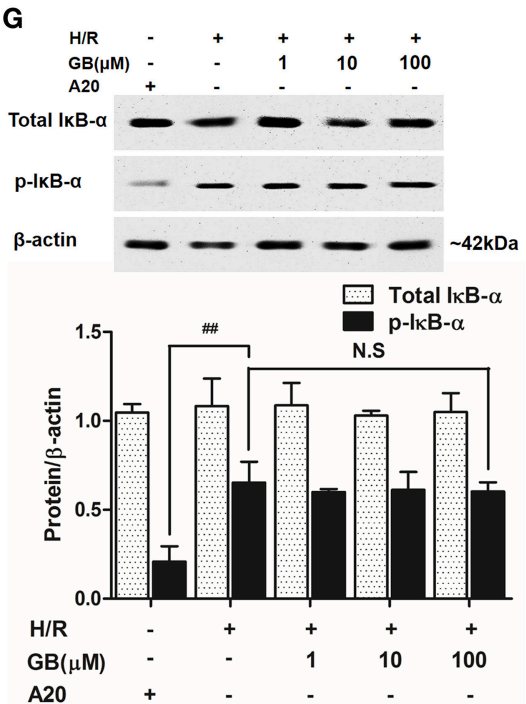
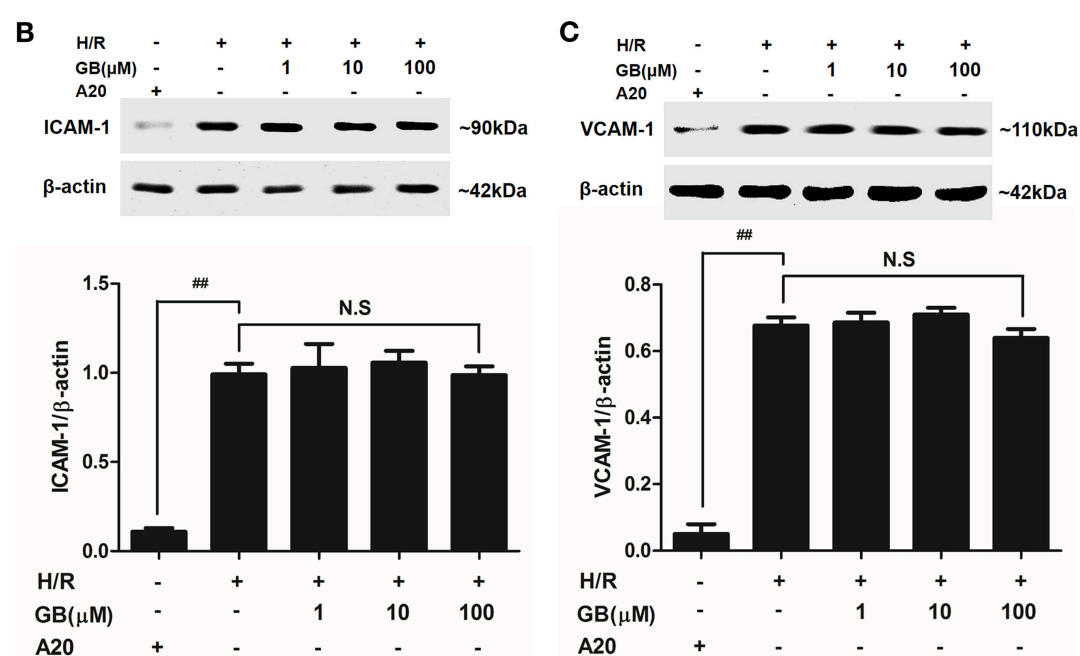

$\mathbf{E}$

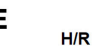

$\mathrm{GB}(\mu \mathrm{M})$

NF-KB p65 -

$-\cdots 65 \mathrm{kDa} \quad \mathrm{NF}-\mathrm{KB} \mathrm{p}$

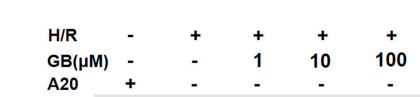

$\beta$-actin $----\sim 42 \mathrm{kDa}$ Histone $-----\sim 17 \mathrm{kDa}$

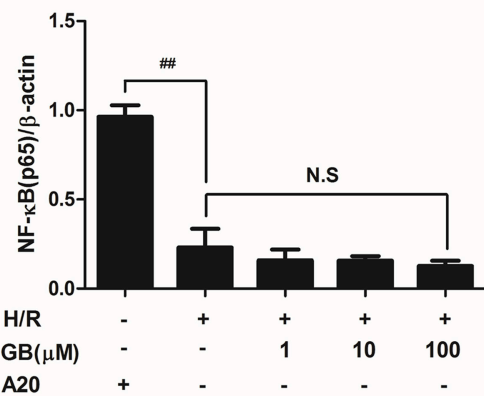

H
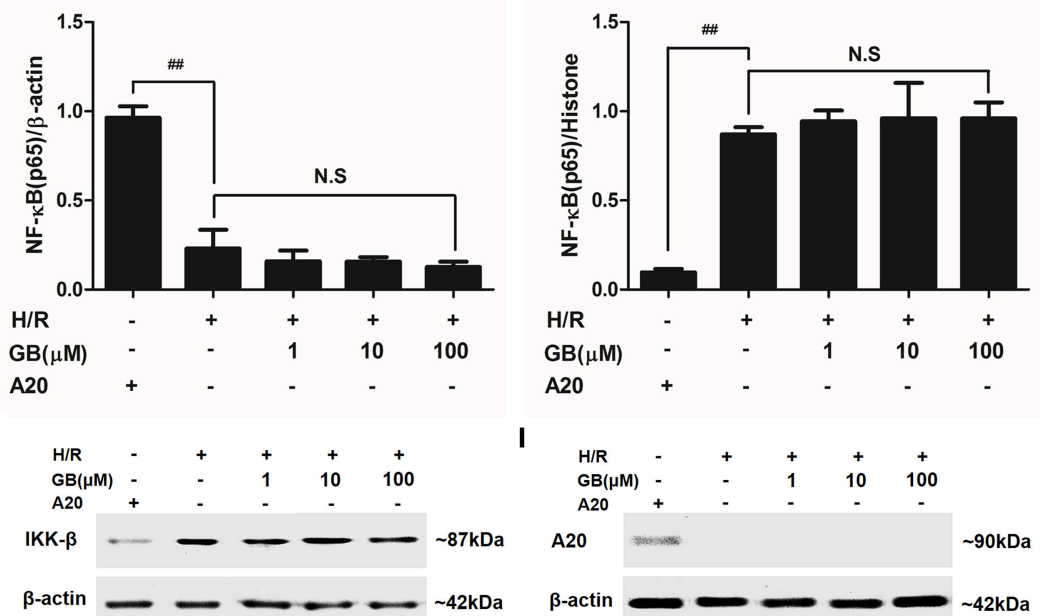

$\beta$-actin $-\sim \sim 2 \mathrm{KDa}$
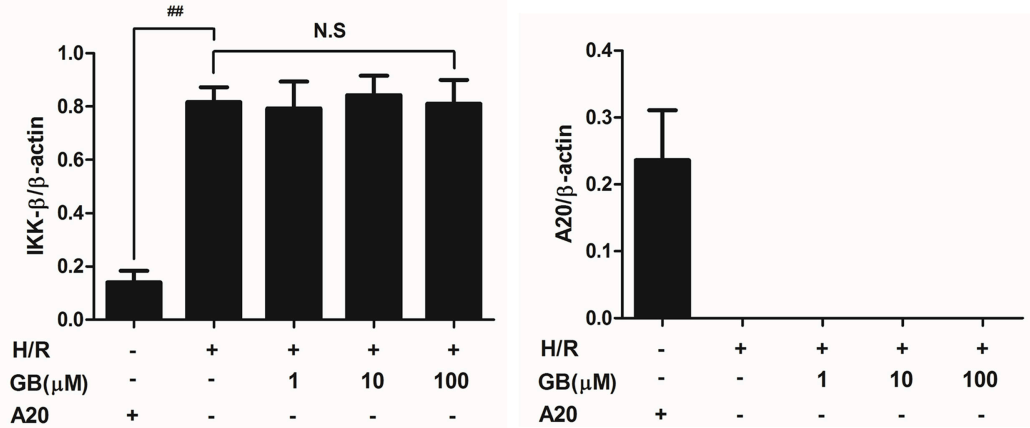

FIGURE 7 | Effects of GB on cell viability (A) and the expressions of (B) ICAM-1, (C) VCAM-1, (D) iNOS, (E) cytoplasm NF-kB p65, (F) nucleus NF-kB p65, (G) $\mathrm{p}-\mathrm{IKB}-\alpha$, (H) IKK- $\beta$ and (I) A20 by Western blot in A20 gene silence $\mathrm{H} / \mathrm{R}$ ventricular myocytes model. Results were expressed as Protein/reference protein ratio. Data were expressed as mean \pm S.D. of three independent experiments. $\# \# P<0.01, \mathrm{H} / \mathrm{R}$ group vs. control group; ${ }^{*} P<0.05,{ }^{\star *} P<0.01,1,10,100 \mu \mathrm{M} \mathrm{GB}$ groups vs. l/R group. 
TABLE 4 | Effects of GB on supernatant inflammatory cytokines in A20 gene silence H/R ventricular myocytes model.

\begin{tabular}{|c|c|c|c|c|}
\hline Group & Concentration ( $\mu \mathrm{M})$ & TNF- $\alpha$ (pg/mL) & IL-1 $\beta$ (pg/mL) & IL-6 (pg/mL) \\
\hline Control & & $4.13 \pm 0.18$ & $69.33 \pm 18.25$ & $16.19 \pm 2.26$ \\
\hline $\mathrm{H} / \mathrm{R}+\mathrm{A} 2 \mathrm{O}^{-}$ & & $72.19 \pm 6.59^{\# \#}$ & $906.19 \pm 73.20^{\# \#}$ & $729.35 \pm 81.00^{\# \#}$ \\
\hline \multirow[t]{3}{*}{$\mathrm{H} / \mathrm{R}+\mathrm{GB}+\mathrm{A} 2 \mathrm{O}^{-}$} & 1 & $68.33 \pm 10.31$ & $872.12 \pm 67.34$ & $681.98 \pm 69.21$ \\
\hline & 10 & $62.18 \pm 5.68$ & $912.33 \pm 89.76$ & $633.10 \pm 58.22$ \\
\hline & 100 & $65.33 \pm 8.32$ & $890.65 \pm 76.38$ & $637.39 \pm 58.31$ \\
\hline
\end{tabular}

Values were expressed as mean $\pm S D(n=8)$.

${ }^{\# \#} P<0.01, H / R$ group vs. control group; ${ }^{\star} P<0.05,{ }^{\star \star} P<0.01,1,10,100 \mu M$ GB groups vs. I/R group.

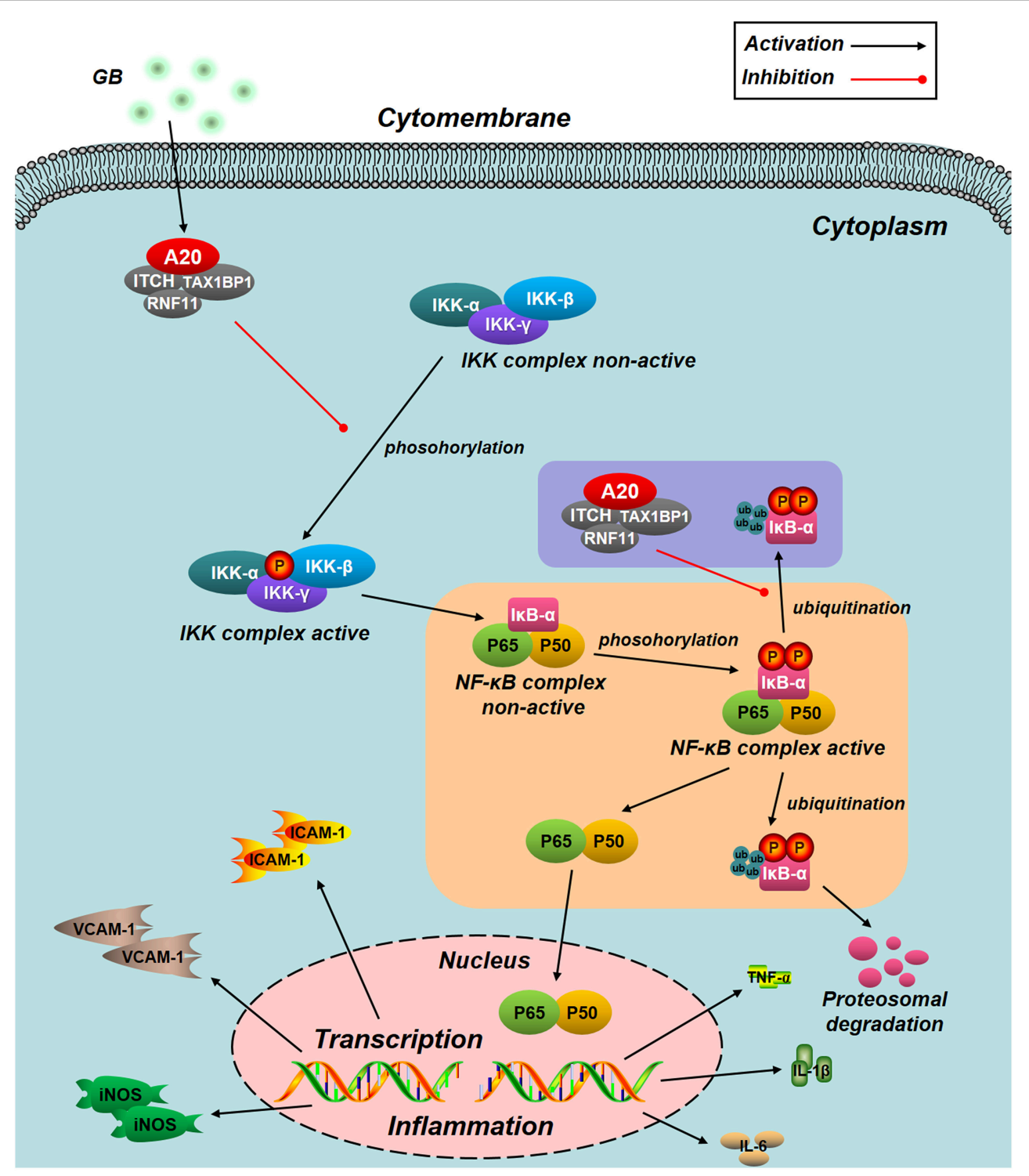

FIGURE 8 | Schematic diagram describing the mechanism in the inhibitory effect of GB on H/R induced ventricular myocytes inflammatory injury. GB could alleviate $\mathrm{MI} / \mathrm{RI}$-induced inflammatory injury via up-regulating $\mathrm{A} 20$ and inhibiting $\mathrm{IKK} / \mathrm{l} \mathrm{B} / \mathrm{NF}-\kappa \mathrm{B}$ signal pathway.

as a key effector in the innate immune system (30). Following $\mathrm{MI} / \mathrm{RI}$, a large increase in the number of circulating PMNs occurred, which could predict the major adverse cardiac events in MI/RI patients with larger infarct size and worse cardiac function (31). Therefore, suppression of PMNs infiltration is a main resource of relieving the damage of MI/RI. In this study, a convincing show of histopathological damage was found in in vivo I/R groups which suggested that there was 
a definite relationship between MI/RI and PMNs infiltration. Nevertheless, pretreatment with GB could significantly attenuate PMNs infiltration, as determined by histopathological scores and the counting of PMNs. MPO, regarded as a precise marker of $\mathrm{MI} / \mathrm{RI}$ and a risk factor for long-term mortality, is secreted by PMNs. Similarly, the elevated level of MPO in I/R groups was decreased after pretreatment with GB. These findings provide a potential link between GB's MI/RI protective effect and PMNs infiltration inhibitory property.

Moreover, in vitro $\mathrm{H} / \mathrm{R}$-treated ventricular myocytes were applied to imitate the pathological process of in vivo $\mathrm{I} / \mathrm{R}$ injury, which helped to thoroughly validate the cardioprotective property of GB. Interestingly, we found for the first time that GB could significantly increase the cell viability after I/R-like insult which indicated that GB could exert anti-MI/RI effect via promoting viability and tolerance of cells injured by $\mathrm{H} / \mathrm{R}$-induced inflammation.

So far, observed data implicate that NF- $\kappa \mathrm{B}$ is deemed as one of the key players in pathogenesis of $I / R$ injury. And they have also shown that active NF- $\mathrm{B}$-mediated signaling significantly increased I/R-induced heart damage (32, 33). NF- $\kappa \mathrm{B}$ functions as a crucial transcription factor in both inflammatory cells and myocardial cells, linking the coordinated inflammatory and cell death signaling pathways proposed in the concept of necroinflammation. However, lots of studies indicated that inhibition of NF- $\mathrm{B}$ signal pathways could remarkably suppress the inflammation induced by MI/RI (3436). Under normal conditions, NF- $\kappa \mathrm{B}$ proteins were bound by members of the inhibitor of $\kappa \mathrm{B}$ (I $\kappa \mathrm{B}$ ) family as components of inactive cytoplasmic complexes $(37,38)$. After ubiquitylation and proteasomal degradation of phosphorylated I $\mathrm{B}$ family members, nuclear translocation of NF- $\kappa \mathrm{B}$ family members would be released (39). In the present work, the level of NF- $\mathrm{B}$ p65 translocation was obviously elevated after H/R procedure. Whereas, our results indicated that GB could effectively reverse this activated effect. In addition, pretreatment with GB could significantly block the notable phosphorylation of IкB$\alpha$ triggered by $H / R$ procedure. These results suggest that the reduction in phosphorylation of I $\mathrm{B}-\alpha$ and translocation of NF$\kappa \mathrm{B}$ p65 is at least one of the targets of GB for inhibiting I/Rinduced inflammation.

Genetic evidence suggests that IKK complex (IKK- $\alpha, \beta$, and $\gamma$ ), a supporting role in activating the NF- $\kappa \mathrm{B}$ pathway, is pivotal for activating phosphorylation-dependent I $\kappa$ B degradation and NF-кB nuclear translocation (40). Therefore, we detected whether GB had an influence on the activity of IKK- $\beta$. Unsurprisingly, GB could also inhibit IKK- $\beta$ activation in $H / R$ injured ventricular myocytes. Consequently, we determined that IKK- $\beta / \mathrm{I} \kappa \mathrm{B}-\alpha / \mathrm{NF}-\kappa \mathrm{B}$ signal pathway was one of the anti-inflammatory targets of $\mathrm{GB}$.

Numerous data have proved that there was a positive feedback between NF- $\kappa \mathrm{B}$ activation and its downstream inflammatory cytokines, such as TNF- $\alpha$, IL- $1 \beta$, and IL-6; cell adhesion molecules, such as ICAM-1 and VCAM-1; and nitric oxide synthase (NOS) (41-43). Therefore, this study has also checked this point. It implies that, blockade of NF- $\kappa B$ pathway by GB has shown positive efficacy in the management of MI/RI induced inflammation.
NF- $\kappa \mathrm{B}$ signal pathway is mediated by several regulatory mechanisms to keep the homeostasis of tissue. Zinc finger protein A20, serves as a tumor suppressor gene and susceptibility gene/biomarker of disease, involved in various inflammatory diseases, especially MI/RI $(44,45)$. Previous studies have verified that A20 was a central and inducible negative regulator of NF$\kappa \mathrm{B}$ which regulates multiple inflammatory signaling cascades. Silencing of A20 can significantly promote the translocation of NF- $\kappa$ B p65, finally leading to a pro-inflammatory state (46). Our present study showed that the level of A20 is low under normal conditions. However, A20 was significantly up-regulated by all GB-treated groups and the consequences were severe inhibition of NF- $\mathrm{B}$ signal pathway. According to the fact, we concluded that the MI/RI protective effect of GB might partly attribute to $\mathrm{NF}-\kappa \mathrm{B}$ inhibition mediated by upregulation of A20. Furthermore, we silence the A20 gene both in vivo and in vitro to verify our hypothesis. After A20 was silenced, GB failed to reduce infarct size, improve cardiac ultrastructural characterization, inhibit PMNs infiltration and downregulate expressions of inflammatory cytokines and proteins in vivo. In addition, GB had no effect on cell viability and inflammatory factors at all (Data Sheet 1 in Supplementary Material). Therefore, it was obvious that GB exerted the protective effect against $\mathrm{MI} / \mathrm{RI}$ through inhibiting NF- $\mathrm{B}$ signal pathway via A20 (Figure 8).

In conclusion, this is the first time to find out that GB alleviated MI/RI-induced inflammatory insult both in vivo and in vitro via up-regulating A20 dependent NF- $\kappa \mathrm{B}$ signal pathway. Thus, GB could be applied as a preventive and valuable agent against MI/RI.

\section{AUTHOR CONTRIBUTIONS}

RZ, LX, DZ, BH, and QL performed the research. RZ, DH, JL, and CS designed the research study. RZ and CS analyzed the data. RZ wrote and edited the paper.

\section{FUNDING}

This study was supported by grants from the Natural Science Foundation of Shandong Province (Program No. ZR2018PH037), National Natural Science Foundation of China (Program No. 81602226, 81572534), China Postdoctoral Science Foundation (No. 2016M590641) and Health Foundation of Shandong Province (No. 2017WS292).

\section{SUPPLEMENTARY MATERIAL}

The Supplementary Material for this article can be found online at: https://www.frontiersin.org/articles/10.3389/fimmu. 2018.02844/full\#supplementary-material

Supplementary Figure 1 | The LPS experimental procedure in vitro.

Supplementary Figure 2 | Effects of GB on cell viability and the expressions of A20, ICAM-1, VCAM-1, iNOS, NF-кB p65, p-ІкB- $\alpha$, IKK- $\beta$ after LPS procedure.

Supplementary Figure 3 | Effects of GB on cell viability and the expressions of A20, ICAM-1, VCAM-1, iNOS, NF-кB p65, p-ІкB- $\alpha$, IKK- $\beta$ after A20 silencing. 


\section{REFERENCES}

1. Ibanez B, Heusch G, Ovize M, Van de Werf F. Evolving therapies for myocardial ischemia/reperfusion injury. J Am Coll Cardiol. (2015) 65:145471. doi: 10.1016/j.jacc.2015.02.032

2. Costa MA, Paiva AE, Andreotti JP, Cardoso MV, Cardoso CD, Mintz A, et al. Pericytes constrict blood vessels after myocardial ischemia. J Mol Cell Cardiol. (2018) 116:1-4. doi: 10.1016/j.yjmcc.2018.01.014

3. Thind GS, Agrawal PR, Hirsh B, Saravolatz L, Chen-Scarabelli C, Narula J, et al. Mechanisms of myocardial ischemia-reperfusion injury and the cytoprotective role of minocycline: scope and limitations. Fut Cardiol. (2015) 11:61-76. doi: 10.2217/fca.14.76

4. Enesa K, Evans P. The biology of A20-like molecules. Adv Exp Med Biol. (2014) 809:33-48.

5. Wertz IE, Newton K, Seshasayee D, Kusam S, Lam C, Zhang J, et al. Phosphorylation and linear ubiquitin direct A20 inhibition of inflammation. Nature (2015) 528:370-5. doi: 10.1038/nature16165

6. Lawless D, Pathak S, Scambler TE, Ouboussad L, Anwar R, Savic S. A Case of Adult-Onset still's disease caused by a novel splicing mutation in TNFAIP3 successfully treated with tocilizumab. Front Immunol. (2018) 9:1527. doi: 10.3389/fimmu.2018.01527

7. Osorio J. Inflammation: A20-NEMO interaction prevents autoinflammation. Nat Rev Rheumatol. (2016) 12:134. doi: 10.1038/nrrheum.2016.19

8. Han D, Fang W, Zhang R, Wei J, Kodithuwakku ND, Sha L, et al. Clematichinenoside protects blood brain barrier against ischemic stroke superimposed on systemic inflammatory challenges through up-regulating A20. Brain Behav Immun. (2016) 51:56-69. doi: 10.1016/j.bbi.2015.07.025.

9. Lee GJ, Lee HM, Kim TS, Kim JK, Sohn KM, Jo EK. Mycobacterium fortuitum induces A20 expression that impairs macrophage inflammatory responses. Pathog Dis. (2016) 74:ftw015. doi: 10.1093/femspd/ftw015

10. Zilberman-Rudenko J, Shawver LM, Wessel AW, Luo Y, Pelletier M, Tsai WL, et al. Recruitment of A20 by the C-terminal domain of NEMO suppresses NF-kappaB activation and autoinflammatory disease. Proc Natl Acad Sci USA. (2016) 113:1612-7. doi: 10.1073/pnas.1518163113

11. Aksentijevich I, Zhou Q. NF-kappaB pathway in autoinflammatory diseases: dysregulation of protein modifications by ubiquitin defines a new category of autoinflammatory diseases. Front Immunol. (2017) 8:399. doi: 10.3389/fimmu.2017.00399

12. Gray CB, Suetomi T, Xiang S, Mishra S, Blackwood EA, Glembotski CC, et al. CaMKIIdelta subtypes differentially regulate infarct formation following ex vivo myocardial ischemia/reperfusion through NF-kappaB and TNF-alpha. J Mol Cell Cardiol. (2017) 103:48-55. doi: 10.1016/j.yjmcc.2017.01.002

13. de Aquino PE, Magalhaes TR, Nicolau LA, Leal LK, de Aquino NC, Dos Santos SM, et al. The anti-inflammatory effects of N-methyl-(2S,4R)-trans-4hydroxy-1-proline from Syderoxylon obtusifolium are related to its inhibition of TNF-alpha and inflammatory enzymes. Phytomedicine (2017) 24:14-23. doi: 10.1016/j.phymed.2016.11.010

14. Hall CHT, Campbell EL, Colgan SP. Neutrophils as components of mucosal homeostasis. Cell Mol Gastroenterol Hepatol. (2017) 4:329-37. doi: 10.1016/j.jcmgh.2017.07.001

15. Wan F, Zang S, Yu G, Xiao H, Wang J, Tang J. Ginkgolide B suppresses methamphetamine-induced microglial activation through TLR4-NF-kappaB signaling pathway in BV2 cells. Neurochem Res. (2017) 42:2881-91. doi: 10.1007/s11064-017-2309-6

16. Hu H, Li Y, Xin Z, Zhanga X. Ginkgolide B exerts anti-inflammatory and chondroprotective activity in LPS-induced chondrocytes. Adv Clin Exp Med. (2018) 27:913-20. doi: 10.17219/acem/70414

17. Zhang M, Sun J, Chen B, Zhao Y, Gong H, You Y, et al. Ginkgolide $\mathrm{B}$ inhibits platelet and monocyte adhesion in TNFalpha-treated HUVECs under laminar shear stress. BMC Complement Altern Med. (2018) 18:220. doi: 10.1186/s12906-018-2284-8

18. Chen A, Xu Y, Yuan J. Ginkgolide B ameliorates NLRP3 inflammasome activation after hypoxic-ischemic brain injury in the neonatal male rat. Int J Dev Neurosci. (2018) 69:106-11. doi: 10.1016/j.ijdevneu.2018.07.004

19. Zheng PD, Mungur R, Zhou HJ, Hassan M, Jiang SN, Zheng JS. Ginkgolide B promotes the proliferation and differentiation of neural stem cells following cerebral ischemia/reperfusion injury, both in vivo and in vitro. Neural Regen Res. (2018) 13:1204-11. doi: 10.4103/1673-5374.232476
20. Pei HX, Hua R, Guan CX, Fang X. Ginkgolide B reduces the degradation of membrane phospholipids to prevent ischemia/reperfusion myocardial injury in Rats. Pharmacology (2015) 96:233-9. doi: 10.1159/000438945

21. Zhang R, Han D, Li Z, Shen C, Zhang Y, Li J, et al. Ginkgolide C alleviates myocardial ischemia/reperfusion-induced inflammatory injury via inhibition of CD40-NF-kappab pathway. Front Pharmacol. (2018b) 9:109. doi: 10.3389/fphar.2018.00109

22. Mukaino M, Nakamura M, Yamada O, Okada S, Morikawa S, Renault-Mihara F, et al. Anti-IL-6-receptor antibody promotes repair of spinal cord injury by inducing microglia-dominant inflammation. Exp Neurol. (2010) 224:403-14. doi: 10.1016/j.expneurol.2010.04.020

23. Agita A, Alsagaff MT. Inflammation, Immunity, and Hypertension. Acta Med Indones (2017) 49:158-65.

24. Messer JS. The cellular autophagy/apoptosis checkpoint during inflammation. Cell Mol Life Sci. (2017) 74:1281-96. doi: 10.1007/s00018-016-2403-y

25. Arfvidsson J, Ahlin F, Vargas KG, Thaler B, Wojta J, Huber K. Monocyte subsets in myocardial infarction: a review. Int J Cardiol. (2017) 231:47-53. doi: 10.1016/j.ijcard.2016.12.182

26. Lv Z, Yang Y, Wang J, Chen J, Li J, Di L. Optimization of the preparation conditions of borneol-modified ginkgolide liposomes by response surface methodology and study of their blood brain barrier permeability. Molecules (2018) 23:E303. doi: 10.3390/molecules23020303

27. Chang J, Xue X, Song C, Liu B, Gao L. Ginkgolide B promotes cell growth in endothelial progenitor cells through miR-126 and the Akt signaling pathway. Mol Med Rep. (2017) 16:5627-32. doi: 10.3892/mmr.2017.7254

28. Gill I, Kaur S, Kaur N, Dhiman M, Mantha AK. Phytochemical ginkgolide $\mathrm{B}$ attenuates amyloid-beta1-42 induced oxidative damage and altered cellular responses in human neuroblastoma SH-SY5Y Cells. J Alzheimers Dis. (2017) 60:S25-40. doi: 10.3233/jad-161086

29. van Hout GP, Bosch L, Ellenbroek GH, de Haan JJ, van Solinge WW, Cooper MA, et al. The selective NLRP3-inflammasome inhibitor MCC950 reduces infarct size and preserves cardiac function in a pig model of myocardial infarction. Eur Heart J. (2017) 38:828-36. doi: 10.1093/eurheartj/ ehw247

30. Gao W, Zhao B, Liu L, Yuan Q, Wu X, Xia Z. Myocardial ischemic postconditioning protects the lung against myocardial ischemia/reperfusioninduced damage by activating GSK-3beta. Acta Cir Bras. (2017) 32:376-87. doi: 10.1590/s0102-865020170050000007

31. Butler T. The Jarisch-herxheimer reaction after antibiotic treatment of spirochetal infections: a review of recent cases and our understanding of pathogenesis. Am J Trop Med Hyg. (2017) 96:46-52. doi: 10.4269/ajtmh.16-0434

32. Yue Y, Yang X, Feng K, Wang L, Hou J, Mei B, et al. M2b macrophages reduce early reperfusion injury after myocardial ischemia in mice: a predominant role of inhibiting apoptosis via A20. Int J Cardiol. (2017) 245:228-35. doi: 10.1016/j.ijcard.2017.07.085

33. Hoshino M, Yonetsu T, Murai T, Kanaji Y, Usui E, Yamaguchi M, et al. Multimodality coronary imaging to predict periprocedural myocardial necrosis after an elective percutaneous coronary intervention. Coron Artery Dis. (2018) 29:237-45. doi: 10.1097/mca.00000000000 00595

34. EMP, Mopuri R, Pulaganti M, Kareem MA, Islam MS, KRDG, et al. Molecular assessment of protective effect of Vitex negundo in ISO induced myocardial infarction in rats. Biomed Pharmacother. (2017) 92:249-53. doi: 10.1016/j.biopha.2017.05.078

35. Erikson JM, Valente AJ, Mummidi S, Kandikattu HK, DeMarco VG, Bender $\mathrm{SB}$, et al. Targeting TRAF3IP2 by genetic and interventional approaches inhibits ischemia/reperfusion-induced myocardial injury and adverse remodeling. J Biol Chem. (2017) 292:2345-58. doi: 10.1074/jbc.M116.764522

36. Yu B, Wang W. cardioprotective effects of morroniside in rats following acute myocardial infarction. Inflammation (2018) 41:432-6. doi: 10.1007/s10753-017-0699-x

37. Kljucevic N, Milat AM, Grga M, Mudnic I, Boban M, Grkovic I. White wine consumption influences inflammatory phase of repair after myocardial infarction in rats. J Cardiovasc Pharmacol. (2017) 70:293-9. doi: $10.1097 /$ fjc. 0000000000000519

38. Mongue-Din H, Patel AS, Looi YH, Grieve DJ, Anilkumar N, Sirker A, et al. NADPH Oxidase-4 driven cardiac macrophage polarization protects against 
myocardial infarction-induced remodeling. JACC Basic Transl Sci. (2017) 2:688-98. doi: 10.1016/j.jacbts.2017.06.006

39. Rothschild DE, McDaniel DK, Ringel-Scaia VM, Allen IC. Modulating inflammation through the negative regulation of NF-kappaB signaling. $J$ Leukoc Biol. (2018) 103:1131-50. doi: 10.1002/jlb.3mir0817-346rrr

40. Samidurai M, Ramasamy VS, Jo J. beta-amyloid inhibits hippocampal LTP through TNFR/IKK/NF-kappaB pathway. Neurol Res. (2018) 40:268-76. doi: 10.1080/01616412.2018.1436872

41. Catrysse L, van Loo G. Inflammation and the metabolic syndrome: the tissue-specific functions of NF-kappaB. Trends Cell Biol. (2017) 27:417-29. doi: 10.1016/j.tcb.2017.01.006

42. Durand JK, Baldwin AS. Targeting IKK and NF-kappaB for therapy. Adv Protein Chem Struct Biol. (2017) 107:77-115. doi: 10.1016/bs.apcsb,.2016.11.006

43. Kondylis V, Kumari S, Vlantis K, Pasparakis M. The interplay of IKK, NFkappaB and RIPK1 signaling in the regulation of cell death, tissue homeostasis and inflammation. Immunol Rev. (2017) 277:113-27. doi: 10.1111/imr.12550

44. Lee HR, Choi J, Lee SH, Cho ML, Jue DM. Intracelluar delivery of A20 protein inhibits TNFalpha-induced NF-kappaB activation. Protein Expr Purif. (2018) 143:14-9. doi: 10.1016/j.pep.2017.10.005
45. Van Quickelberghe E, Martens A, Goeminne LJE, Clement L, van Loo G, Gevaert K. Identification of Immune-Responsive Gene 1 (IRG1) as a Target of A20. J Proteome Res. (2018) 17:2182-91. doi: 10.1021/acs.jproteome. $8 \mathrm{~b} 00139$

46. Jarosz M, Olbert M, Wyszogrodzka G, Mlyniec K, Librowski T. Antioxidant and anti-inflammatory effects of zinc. Zinc-dependent NF-kappaB signaling Inflammopharmacology (2017) 25:11-24. doi: 10.1007/s10787-0170309-4

Conflict of Interest Statement: The authors declare that the research was conducted in the absence of any commercial or financial relationships that could be construed as a potential conflict of interest.

Copyright (c) 2018 Zhang, Xu, Zhang, Hu, Luo, Han, Li and Shen. This is an openaccess article distributed under the terms of the Creative Commons Attribution License (CC BY). The use, distribution or reproduction in other forums is permitted, provided the original author(s) and the copyright owner(s) are credited and that the original publication in this journal is cited, in accordance with accepted academic practice. No use, distribution or reproduction is permitted which does not comply with these terms. 